\title{
International Crimes or Ordinary Crimes? The 'Dual Classification of the Facts' as an Interpretive Method
}

\author{
Elena Maculan \\ Department of Criminal Law and Criminology, Universidad Nacional \\ de Educación a Distancia, \\ Calle de Bravo Murillo, 38, 28015 Madrid, Spain \\ emaculan@der.uned.es
}

\begin{abstract}
Many domestic courts, when prosecuting atrocities committed in their dictatorial or warring past, have been facing a real dilemma: whether to classify the facts as ordinary crimes, foreseen by the domestic legislation prior to the facts and therefore consistent with the principles of legality and non-retroactivity, or as international crimes, which do not grant the same compatibility but allow to overcome the obstacles to prosecution imposed by statutory limitations and amnesties. The paper focuses on an interpretative method developed by several Latin American tribunals to overcome this impasse, by means of a combined application of the two criminal categories. Although this 'dual classification of facts' apparently solves the dilemma, it is flawed from both a methodological and substantive perspective. After scrutinising these problematic issues, the paper analyses some alternative interpretative proposals that may also allow to avoid impunity, but without impinging on fundamental principles of modern criminal law systems.
\end{abstract}

\section{Keywords}

dual classification of the facts - principle of legality - non-retroactivity - LatinAmerican jurisprudence - international crimes - amnesties - statutory limitations 
The present (and probably the future) of International Criminal Law is played out in national courts. The consolidation of the duties of criminal prosecution and punishment imposed by International Law, on the one hand, and the principle of complementarity that governs the operation of the International Criminal Court (ICC), on the other, are giving States an increasing role in responding to serious violations of human rights that can be classified as international crimes. ${ }^{1}$

At the same time, when criminal proceedings are conducted at the national level, it is necessary to take into account the legislative and constitutional framework of the relevant legal system, including principles and limits that may conflict with the objective of responding to such atrocities. These tensions have often arisen in connection with events which, although they at least appear to fit the definition of international crimes (because of their gravity, their broad dimensions, their systematic and widespread nature $)^{2}$, occurred at a time prior to the legislative provision for these types of offences in the national system.

This situation creates a real dilemma for the criminal courts between two interpretative solutions: whether to classify the facts as ordinary offences, envisaged in the corresponding national legislation prior to the facts, or as international crimes, introduced after the facts. Both have a very high cost either in terms of respect for the principles and guarantees of criminal systems or avoiding impunity.

Among the arguments developed by the national courts to resolve this dilemma is a strikingly original exercise of interpretation which has been

1 R. Cryer, D. Robinson and S. Vasiliev, An Introduction to International Criminal Law and Procedure, 4th edn. (Cambridge University Press, Cambridge, 2019), p. 553; C. Stahn, An Introduction to International Criminal Law (Cambridge University Press, Cambridge, 2018), pp. 189-192, pointing out the advantages and drawbacks of prosecution at the domestic level. Drumbl too calls for 'renationalisation' of International Criminal Law as a future challenge: M. Drumbl, 'The Future of International Criminal Law and Transitional Justice', in W. Schabas, Y. McDermott and N. Hayes (eds.), The Ashgate Research Companion to International Criminal Law (Ashgate, Burlington, 2013), 531-545, p. 540.

2 Leaving aside the ongoing debate as to the distinguishing feature(s) that allows the inclusion of an offence within this category: see the description of the positions (and the reductionist conclusion) offered by R. O'Keefe, International Criminal Law (Oxford University Press, Oxford, 2015), p. 47 et seq.; see also the philosophical approach by A. Chehtman, 'A Theory of International Crimes: Conceptual and Normative Issues', in K.J. Heller, F. Mégret, S. Nouwen, J. Ohlin and D. Robinson (eds.), The Oxford Handbook of International Criminal Law (Oxford University Press, Oxford, 2020), p. 317. 
called dual classification of the facts. ${ }^{3}$ The method consists of classifying the facts that are the subject of the proceedings under two categories at the same time: on the one hand, as ordinary crimes, as defined by the criminal legislation of that country, and on the other, as international crimes.

This is a line of argument that was inaugurated by a Spanish court, but that is found mainly in the case law of several Latin American countries (Colombia, Chile, Peru and, above all, Argentina). At first sight this method allows the combining of the positive effects of the two possible categories mentioned above (as ordinary crimes and as international crimes) and to overcome their negative aspects. However, a more detailed analysis shows that dual classification poses major problems, both methodologically and in terms of compatibility with constitutional principles.

Although the mechanism in itself has already been described by scholarly literature in relation to some concrete judicial cases, there is no overall assessment of it as an interpretative technique. ${ }^{4}$ Furthermore, it has usually been praised as a technique to fight against impunity for international crimes, ${ }^{5}$ but without dwelling in all its implications and possible 'dark sides'. This article precisely offers an in-depth and critical analysis of this interpretative method, not limited to a single judicial decision but considering it as a pattern in domestic jurisprudence.

After a description of the case law where the method has been used (Section 2), breaking down its background (Section 2.1), its subject matter (Section 2.2) and its effects (Section 2.3), it goes on to study its critical aspects (Section 3) from the methodological (Section 3.1) and ontological (Section 3.2) standpoint. Lastly, Section 4 offers some alternative interpretative proposals that may help to reach the purpose behind this technique (namely, avoiding impunity) but without this amounting to an infringement of fundamental criminal law principles. Special attention is paid to a line of reasoning according to which the time barring should be considered suspended during the validity of the dictatorial regime in which the abuses were committed. Despite not being exempt

3 In Spanish, 'doble subsunción de los hechos.' Another translation that has been proposed is 'double classification of the facts of the case': P. Parenti, 'The Prosecution of International Crimes in Argentina', 10 International Criminal Law Review (2010) 491-507, p. 498.

4 See, for example: L. Grover, Interpreting Crimes in the Rome Statute of the International Criminal Court (Cambridge University Press, Cambridge, 2014), pp. 162-5; Parenti, supra note 3, p. 491; W.N. Ferdinandusse, Direct Application of International Criminal Law in National Courts (TMC Asser Press, The Hague, 2006), p. 29 et seq.

5 Parenti, supra note 3, p. 491; M. Ollé Sesé, Justicia universal para crímenes internacionales (La Ley, Madrid, 2008), p. 179. 
from critical aspects, this proposal allows to overcome the statute of limitations obstacle, without forcing to a retroactive application of criminal law.

\section{Judicial Application of the Dual Classification of the Facts}

2.1

\section{The Background: Facing a Dilemma}

The judicial decisions that are analysed here are nearly all to do with the atrocities committed during the dictatorships that governed the countries of the Latin American continent from the 1970s to the 199os (such as Argentina, Chile, Peru), or during the armed conflicts that broke out in that same geographical area (Colombia). ${ }^{6}$ In all these experiences of collective violence, acts were committed which, because of their gravity, their broad dimensions and their systematic nature, and because they were mainly directed against civilians, seem to fit the description of international crimes, and very especially crimes against humanity. The attribution of this classification entails the application of the so-called special regime for international crimes, that is, a set of rules derogating from the ordinary treatment of common offences. This is a regime that has been consolidated in recent decades, mainly thanks to the interpretative work of the Human Rights Courts (among which the Inter-American Court of Human Rights, IACtHR, stands out) ${ }^{7}$ and the Statutes of the ICC and several internationalised criminal courts. ${ }^{8}$ Although their exact content is still under discussion, there is now some consensus on their main features, which are: non-applicability of statutory limitations, the impossibility

6 For a brief account of these transitional experiences, see, e.g., the contributions in J. Almqvist and C. Espósito, The Role of Courts in Transitional Justice. Voices from Latin America and Spain (Routledge, Abingdon, 2012) and those collected in Volume 10, Issue 4 (2010) of the International Criminal Law Review; see also K. Ambos, E. Malarino and G. Elsner (eds.), Justicia de transición (Konrad Adenauer Stiftung, Montevideo, 2009).

7 A very critical appraisal of this jurisprudence can be found in E. Malarino, 'Judicial activism, punitivism and supranationalisation: Illiberal and antidemocratic tendencies of the InterAmerican Court of Human Rights', 12(4) International Criminal Law Review (2012) 665-695.

8 Ibid., note 7; E. Maculan, Los crímenes internacionales en la jurisprudencia latinoamericana (Marcial Pons, Madrid, 2019), pp. 71-87. On the inadmissibility of amnesties, see J. Close, Amnesty, serious crimes and International Law. Global Perspectives in Theory and Practice (Routledge, Abingdon, 2019), p. 215 et seq. and (from the complementary perspective of the duty to prosecute serious human rights violations) A. Seibert-Fohr, Prosecuting Serious Human Rights Violations (Oxford University Press, Oxford, 20o9); on statutory limitations for international crimes, see R. Kok, Statutory Limitations in International Criminal Law (Asser Press, The Hague, 2007). 
of making them subject to amnesties (nor, according to a stricter interpretation, to pardons) and the application of the principle of universal jurisdiction. ${ }^{9}$

It is precisely the applicability of this special regime that is of great relevance in the experiences mentioned, since it opens up a range of possibilities for overcoming certain obstacles to the exercise of criminal action that have been raised there.

Firstly, in all these countries transitional processes have taken place (or are still taking place) which seek to combine the need to provide a legal response to the atrocities committed with the objectives of breaking with the past and achieving peace and reconciliation. The transitional framework poses specific challenges and objectives that often lead to limiting or redesigning the exercise of criminal action. ${ }^{10}$ This may be manifested in the adoption of amnesties, which prevent criminal prosecution and/or the imposition of sanctions, or in other mechanisms which, in various ways, limit or delay the activation of criminal jurisdiction. These measures sometimes mirror the clear intention of national institutions to guarantee impunity for those responsible for atrocities (perhaps because they still have a certain amount of power under the new regime), as was the case in Chile. ${ }^{11}$ At other times, however, they represent a necessary solution in view of the impossibility of bringing to court all the crimes committed and all the subjects involved, also taking into account the contingent institutional weakness and the specific, priority objectives of the time of transition..$^{2}$ This would be the case of the transitional process currently underway in Colombia. ${ }^{13}$ Regardless of the genuineness of the

9 Maculan, supra note 8, pp. 71-87.

10 As the first book that dealt with this topic in a comprehensive manner already noted: R. Teitel, Transitional Justice (Oxford University Press, Oxford, 200o), p. 27 et seq. On the inner tensions about the competing goals of a transitional process, see B.A. Leebaw, 'The Irreconciliable Goals of Transitional Justice', 3 o Human Rights Quarterly (2008) 95-118, p. 98 et seq.

11 Amnesty Decree No. 2191 of 18 April 1978, passed by Pinochet's government to cover their own offences, was uphold by the 1980 Constitution and kept into force even after the recovery of the democratic rule in 1988: see C. Collins, 'Human Rights Trials in Chile during and after the Pinochet years', 4 International Journal of Transnational Justice (2010) 67-86.

E. Maculan and A. Gil, 'The Rationale and Purposes of Criminal Law and Punishment in Transitional Contexts', 40(1) Oxford Journal of Legal Studies (2020) 132-157, pp. 149-151.

13 Actually, amnesties are more easily accepted as a legitimate tool to put an end to an ongoing armed conflict even by actors that maintain a general ban on these measures, as it can be seen in the seminal judgement of the IACtHR, El Mozote Massacre v. El Salvador (Series C no. 252), 25 October 2012. The Colombian peace process, which has been labelled as a 'transition without a transition' (R. Uprimny Yepes, M.P. Saffon Sanín, C. Botero Marino and E. Restrepo Saldarriaga, 'Justicia transicional sin transición? Verdad, justicia y reparación para Colombia', DeJusticia (2006) 11-16), has been applying a combination of amnesty 
intentions behind these measures, what is clear is that the approval of provisions for amnesty, pardon or similar measures implies a significant alteration, or even paralysis, of the exercise of criminal action. ${ }^{14}$

Secondly, the passage of time without criminal trials (due, in these contexts, to the paralysis imposed by amnesty laws, to practical impossibility or other reasons) brings statutory limitations into play, pursuant to the regulation set by national criminal law. Even where criminal trials have taken place, there often remains a considerable number of offences that have not yet been investigated, owing to the volume and complexity of the criminal dynamics involved. Therefore, a very frequent outcome of trials relating to such events would be the declaration of the extinction of criminal liability due to the statute of limitations, without any satisfactory investigation having been offered on what happened.

Thirdly, in situations of impunity for serious human rights violations committed by national institutions, one tool that has proved particularly useful is the principle of universal jurisdiction, which allows third party states (other than the state where the crimes have been committed and the state of the nationality of the subjects concerned) to open criminal proceedings in relation to such acts. ${ }^{15}$ This principle, which, moreover, is not provided for in all national systems, nor is it regulated in a uniform manner, is limited in scope to certain categories of offences, among which international crimes stand out. ${ }^{16}$

The limits imposed by the existence of amnesty laws and similar measures, by the statute of limitations and by the scope of universal jurisdiction explain the interest that many domestic courts show in the classification of facts as

and pardons (for political crimes and related offences), selective criminal prosecution and alternative sanctions: see the contributions collected in F.A. Diaz Pabon (ed.), Truth, Justice and Reconciliation in Colombia Transitioning from Violence (Routledge, Abingdon, 2018).

14 C. Murphy, 'Transitional Justice, Retributive Justice and Accountability for Wrongdoing', in C. Corradeti, N. Eisikovits and J. Rotondi (eds.), Theorizing Transitional Justice (Ashgate, Farnham, 2015), pp. 59-68. For an account on the progressive invalidation of amnesty laws in the region, see L. Mallinder, 'The End of Amnesty or Regional Overreach? Interpreting the Erosion of South America's Amnesty Laws', 65 International and Comp. Law Quarterly (2016) 645-68o.

15 See, among many others, F. LaFontaine, 'Universal Jurisdiction: the Realistic Utopia', 10 Journal of International Criminal Justice (2012) 1277-1302; R. O'Keefe, 'Universal Jurisdiction: Clarifying the Basic Concept', 2 Journal of International Criminal Justice (2004) 735-76o; more recently and with a de lege ferenda proposal, Manuel Ollé Sesé, Crimen internacional y jurisdicción penal nacional: de la justicia universal a la jurisdicción penal interestatal (Aranzadi, Cizur Menor, 2019).

16 See, for example, Article 6(1 $1^{\circ}$ bis $)$ of the Belgian Criminal Procedural Code; Article 23(4) of the Spanish Ley Orgánica del Poder Judicial; Section 2 of the Dutch International Crimes Act of 2003 . 
international crimes, which then represents a clear route for overcoming these obstacles.

Yet, this category of crime has been introduced, in all the systems mentioned above, at a much later stage than the acts being prosecuted, and in some of them it has not yet been criminalised. ${ }^{17}$ For this reason, its application would constitute a violation of the principle of legality and especially of one of its components, the non-retroactivity of criminal law.

The principle of non-retroactivity, which is recognised not only in national Constitutions and criminal legislation, but also in several international legal instruments, ${ }^{18}$ prevents the application of a criminal law to acts that occurred before its entry into force, insofar as such a law would have an adverse effect on the accused. The problem is that, while in International Law and in Anglo-Saxon systems this 'norm' may be contained in a written law, in case law or in custom, in continental systems (including the Latin American systems we are analysing) only laws formally approved by Parliaments are considered valid sources of incrimination. ${ }^{19}$

Judges called upon to rule on the responsibility for atrocities committed in the context of the above-mentioned experiences of collective violence are therefore faced with a dilemma: if they classify the offences as international crimes, they can adequately reflect the criminal phenomenology and its gravity, and can also apply the special rules for the criminal prosecution of such crimes. But this classification generates an insurmountable conflict with the principle of legality and that of non-retroactivity of unfavourable criminal law, ${ }^{20}$ both protected by the Constitutions of these systems.

17 Thus, in Peru crimes against humanity were introduced in the Criminal Code by Law 27.636 of 16 January 2002 (Section xIV-A, 'delitos contra la humanidad'); Uruguay passed its Law 18.026 of 13 September 2006 to criminalise this category; in Argentina it made its first appearance in 1995, when Law 24.584 implemented the 1968 Convention on the NonApplicability of Statutory Limitations, although without providing a definition of the offence; the Colombian Criminal Code does not define this category yet.

18 See the massive comparative study by K. Gallant, The Principle of Legality in International and Comparative Law (Cambridge University Press, Cambridge, 2009), which shows that almost all UN member States affirm expressly this principle, as well as many international treaties and the practice of international tribunals.

19 This requirement, which is a corollary of the principle of legality in criminal law is known as the 'principle of reservation of law', and it is established in all the Constitutions and Penal Codes of the Latin-American countries that are considered in this study. See infra, section 3.2.1.

20 Although qualifying a fact as an international crime normally requires an additional effort in terms of providing evidence (which has to cover also the contextual element, and not only the single illegal act), and can therefore make it more difficult to come to a conviction, 
On the other hand, the option of classifying the facts as ordinary offences normally provided for in national legislation makes it possible to respect these fundamental principles, albeit not adequately reflecting the seriousness, scale and structure of the criminal phenomena being judged. Moreover, this classification prevents recourse to the special regime for international crimes and almost certainly leads to impunity due to statutes of limitations or the application of amnesties.

It is clear that both options are unsatisfactory, and this sets the scene for the inevitable conflict between the limits derived from the fundamental principles and guarantees in a democratic State governed by the rule of law, on the one hand, and the impulses of natural justice to prevent such aberrant acts from going unpunished, on the other. Faced with this dilemma, several national criminal courts have been developing very interesting interpretative proposals to minimise or control this conflict. And the method that, it would appear, allows a balance to be struck between these conflicting objectives is that of dual classification.

\subsection{The Subject Matter: Mass Atrocities Committed Under Past Dictatorships or During Armed Conflicts}

Although the factual context within which the method of dual classification is being developed essentially coincides with the atrocities committed during Latin American dictatorships and armed conflicts, a precursor can be identified in the well-known Finta ruling, handed down by the Canadian Supreme Court. ${ }^{21}$ The Canadian court, in judging conducts carried out by the accused during the Holocaust in Hungary, classified the facts as ordinary offences of illegal confinement, robbery, kidnapping and reckless homicide, but derived the legitimacy to exercise jurisdiction from their parallel and subsequent classification as international crimes. ${ }^{22}$

Similarly, the judgement of the Spanish Supreme Court in the Scilingo case, ${ }^{23}$ which convicted the former Argentine lieutenant commander Adolfo

this category is normally punished according to higher sentencing framework, thereby amounting to an unfavourable criminal law.

21 Canadian Supreme Court, R. v. Imre Finta, 24 March 1994. In the jurisprudence of the early international criminal tribunals one can also find examples of a similar 'reclassification of the offence', according to which the conducts were defined as wrongful in preexisting domestic legislation, whereas international law only added some aggravating or jurisdictional elements: Grover, supra note 4, pp. 162-165.

22 Ferdinandusse, supra note 4, pp. 33-35.

23 Spanish Supreme Court (Tribunal Supremo), Criminal Chamber, Judgement 798/2007, appeal in cassation no. 10049/2006 P, 1 October 2007. 
Scilingo for acts committed in the context of the illegal repression of political opposition by the dictatorship of the military juntas in Argentina, also applies the category of international crimes in order to support the exercise of criminal action based on the criterion of universal jurisdiction. In reality, this judgment labels the facts as ordinary crimes of murder and illegal detention, and insists that it is not possible to subsume them under the category of crimes against humanity (thus reforming the categorisation applied by the Audiencia Nacional, Trial Court in the first instance in the same case) $)^{24}$. The argument used by the Supreme Court is that Article 607 of the Criminal Code governing this category of crime was introduced long after the acts being prosecuted had been committed, and its application would entail a violation of the principle of non-retroactivity of criminal law. But, at the same time, it considers it important to recognise that the specific circumstances in which they occurred, and which correspond perfectly to the description of the contextual element of crimes against humanity, can be taken into account, aside from the type of crime, for sentencing and to underpin the exercise of jurisdiction by a Spanish court, in application of the principle of universal jurisdiction. In other words, although the Court tries to maintain an apparent respect for the principle of legality and non-retroactivity, the evaluation of the circumstances aside from the definition of the crime becomes an artifice to obtain the same effect: the imposition of a more severe penalty and the legitimation of the exercise of universal jurisdiction. ${ }^{25}$

Dual classification appears most frequently in the case law of the Latin American continent, where it has been used on several occasions in relation

24 Pre-Trial Court (Juzgado de Instrucción) No. 5 had proposed the subsumption of the conducts under the category of genocide, based on an excessively broad interpretation of the notion of a national group protected by the norm, while the Trial Court (Spanish National Court (Audiencia Nacional), Criminal Chamber, Third Section, Judgement No. 16/2005, Scilingo Manzorro, Adolfo, Summary 19/1997, 19 April 2005) qualified the conducts as crimes against humanity despite the fact that they had been criminalised at a later time. The Trial Court argued that the inclusion of this category in the Spanish legal system implied the assumption of the scope of the corresponding international norm also at a spatial-temporal level (cf. point 4.2 of the judgement). For a critical analysis of this judgement, see A. Gil, 'The Flaws of the Scilingo Judgement', 3(5) Journal of International Criminal Justice (2005) 1082-1091; and Christian Tomuschat, 'Issues of Universal Jurisdiction in the Scilingo Case', 3(5) Journal of International Criminal Justice (2005)1074-1081.

25 A. Gil Gil, 'Principio de legalidad y crímenes internacionales. Luces y sombras en la sentencia del Tribunal Supremo en el caso Scilingo', in A. Cuerda Riezu and F. Jiménez García (eds.), Nuevos desafios del Derecho Penal Internacional. Terrorismo, crímenes internacionales y derechos fundamentales (Tecnos, Madrid, 2009) 391-409. 
to atrocities committed by the dictatorial regimes that were in power in many countries in that area, or by parties to internal armed conflicts.

Thus, a number of judgements of Argentine courts have punished the widespread practice of kidnapping political dissidents, keeping them in clandestine detention centres, subjecting them to torture and failing to give reasons for their whereabouts, ${ }^{26}$ as ordinary offences of unlawful deprivation of liberty and torture, but at the same time claiming their classification as crimes against humanity. ${ }^{27}$ This criminal category appeared in Argentine legislation with Law 24,584, promulgated on 23 November 1995, implementing the 1968 Convention on the Non-Applicability of Statutory Limitations to War Crimes and Crimes Against Humanity. ${ }^{28}$ However, this law, which is subsequent to the events, does not even offer a true description of the category, but refers to the text of the 1968 Convention, which in turn refers to the Statute of the International Military Tribunal in Nuremberg to define crimes against humanity.

In view of the foreseeable objection that this type of crime was not provided for in domestic legislation at the time the acts were committed, the courts

26 For a detailed description of the illegal practices by the Argentine military dictatorship, see the Report issued by the Truth Commission created at the outset of the recovered democracy: CONADEP, Nunca más, 1984 (an English version, 'Never again', is available online at http://www.desaparecidos.org/nuncamas/web/english/library/nevagain/nevagain_oo1. $\mathrm{htm})$.

27 Federal Criminal Trial Court (Tribunal Oral en lo Criminal Federal) no. 1 of San Martín, Riveros, Omar Santiago and others (Case no. 2046 and its accumulates no. 2208), Judgement, 5 May 2011, pp. 282-283; Federal Criminal Trial Court of Neuquen, Reinhold, Oscar Lorenzo Case No. 10.6og, et al. About deprivation of liberty (Case no. 666- $\mathrm{F}^{\circ}$ 69-Year 2008), Judgement, 1 February 2009, p. 500 et seq. (developed mainly in Judge Albrieu's concurring opinion), confirmed in second instance (Federal Criminal Appeals Court (Cámara Federal de Casación Penal), Chamber IV, Reinhold, Oscar Lorenzo et al. on appeal (Case no. 10.6og), Appeals Judgement, 13 February 2012); Federal Criminal Trial Court of Tucumán, Romero Niklison María Alejandra on her request (Case no. 401.118/04 and its accumulations, Case No. 401.118/o4), Judgement, 31 March 2011, p. 110 et seq.; Federal Criminal Trial Court no. 1 of Córdoba, Videla, Jorge Rafael and others and Menéndez, Luciano Benjamín (cases no. 172/o9 and M-13/o9), Judgement, 22 December 2010, p. 295 et seq. The opinion of the Argentine Attorney General's Office in the well-known Simón case (which declared the unconstitutionality of the Due Obedience and Full Stop Laws) also contains a similar affirmation, stating that, along with the subsumption under common crimes, the facts are recognised 'an additional attribute - the condition of crimes against humanity, with the consequences that this implies': Argentine Supreme Court, (Corte Suprema de Justicia de la Nación), Simón, Julio Héctor et al. about illegal deprivation of liberty (causa no. 17.768, S.1767.XxxviII), Judgement, 14 June 2005, Argentine Attorney General's Office (Fiscalía General de la Nación), Dr. N. Becerra's 'Opinion', para. Ix(9) (free translation).

28 Adopted and opened for signature, ratification and accession by General Assembly, Resolution 2391 (XXIII) of 26 November 1968. Entry into force: 11 November 1970. 
invariably argue that it was part of international customary law and as such can be applied under Article 118 of the Argentine Constitution, which refers to crimes 'against the law of nations'. ${ }^{29}$ All these judgements then go on to declare that, by virtue of their status as crimes against humanity, the facts are not subject to any statute of limitations. ${ }^{30}$

But the method is not exclusive to Argentine courts: it also appears, for example, in a Chilean Supreme Court ruling in the Vásquez Martínez and Superby Jeldres case. ${ }^{31}$ Here the court subsumes the facts under the ordinary category of homicide and at the same time under the crime against humanity of murder, alleging that the latter was not criminalised in national legislation, but existed as an international customary norm at the time of the facts. ${ }^{32}$ The consequence that the court draws from this dual classification is the affirmation that statute of limitations does not apply to the facts prosecuted, thus rejecting the defence's request to declare the extinction of criminal responsibility. ${ }^{33}$

The Peruvian Supreme Court, in the well-known Fujimori case, ${ }^{34}$ also opted for a cumulative solution, subsuming the events that occurred in Barrios Altos and La Cantuta under the categories of aggravated kidnapping, aggravated homicide and grievous bodily harm, pursuant to the Peruvian criminal code, ${ }^{35}$ but classifying them as 'crimes against humanity according to international

29 ' $[\mathrm{W}]$ hen this [a crime] is committed outside the limits of the Nation, against the Law of the People, Congress shall determine by a special law the place where the trial is to be followed'.

30 Federal Criminal Trial Court (FCTC) no. 1 of San Martín, Riveros case, supra note 27, pp. 282-283; FCTC of Neuquen, Reinhold case, supra note 27, p. 500 et seq.; FCTC of Tucumán, Romero Niklison supra note 27, p. 110 et seq.; FCTC no. 1 of Córdoba, Videla case, supra note 27, p. 295 et seq.

31 Chilean Supreme Court (Corte Suprema), Criminal Chamber, Molco case (Vásquez Martínez and Superby Jeldres), role n. 559-2004, Judgement, 13 December 2006. The case was about the killing by a military group of two members of a leftist political party (Movimiento de Izquierda Revolucionaria, MIR), in 1973. The accused were acquitted in the first instance judgement, due to the statutory limitation applicable to the crime of murder, and the decision was upheld in the appeals judgement.

$32 \quad$ Ibid., para. 25 .

33 Ibid., para. 27.

34 Supreme Court of Peru (Corte Suprema de Justicia), Special Criminal Court, Fujimori Fujimori, Alberto (Case no. A.V. 19-2001), Judgement, 7 April 2009. The judgement convicted former dictator Alberto Fujimori to 25 years in prison as an indirect perpetrator, by means of the control of an organised power apparatus, of multiple aggravated murders, multiple aggravated injuries and two aggravated kidnappings. See K. Ambos, 'The Fujimori Judgement-A President's Responsibility for Crimes Against Humanity as Indirect Perpetrator by Virtue of an Organized Power Apparatus', 9Journal of International Criminal Justice (2011) 137-158.

35 Articles 152(2), 108 and 121 Peruvian Penal Code, respectively. 
criminal law', ${ }^{36}$ as they were part of a 'State policy of selective but systematic elimination of alleged members of subversive groups, ${ }^{37}$ directed from the highest echelons of the State, which affected many defenceless members of the civilian population..$^{38}$

The validity of this option has been confirmed both by the Constitutional Court in the same proceedings ${ }^{39}$ and by a subsequent Supreme Court ruling in 2018, which has declared the unconstitutionality of the pardon granted to Fujimori himself by former president Kuczynski at the end of 2017 in relation to these events:

The consideration of the crimes of murder and grievous bodily harm as crimes against humanity in no way contravenes the principle of legality. The subsumption of the conduct is not changed: Alberto Fujimori was convicted of murder and injury. [...] There is a substantial difference between, on the one hand, the application of the international criminal definition of crimes against humanity and, on the other hand, the application of the national criminal definitions in force at the time of the commission of the acts simply accompanied by the classification-but not application of nor conviction for-crimes against humanity. ${ }^{40}$

A peculiarity of the Fujimori ruling is that the classification of the facts as crimes against humanity does not entail any practical consequences: neither the non-applicability of the statute of limitations nor the inapplicability of amnesties is declared. Furthermore, the sentence is determined according to the sanctioning frameworks established in the Peruvian Penal Code for the ordinary crimes of homicide, bodily harm, and kidnapping, without applying

36 Supreme Court of Peru, Fujimori, supra note 34, disposition, point II (para. 823), and paras 710 et seq. of the reasoning.

37 Ibid., para. 717 .

38 Crimes against humanity were criminalised in the Peruvian Penal Code (in Title XIV-A) with Law 26.926 of 1998, which at the same time repealed Chapter V of Title I, Book II, 'Genocide'. In its current text, they include genocide, forced disappearance, torture, discrimination and genetic manipulation. However, the legal definition of the offences lacks the contextual element of crimes against humanity, i.e., the massive or systematic attack on a civilian population.

39 Peruvian Constitutional Court (Tribunal Constitucional), Habeas corpus request filed by Alberto Fujimori (Case no. o146o-2016-PHC/TC), Judgement, 3 May 2016, paras 25 and 27, recalling that 'the reference to crimes against humanity has a declaratory character'.

40 Supreme Court of Justice of Peru, 'Control of Conventionality n. oooo6-2001-4-50o1-SU-PE-O 1', 3 October 2018 (free translation). 
any aggravating circumstance based on the context in which the acts were committed. ${ }^{41}$

The reason for this apparent contradiction is, in part, due to the limits imposed by the extradition procedure that permitted this criminal trial. The principle of dual criminality, in effect, prevented the Peruvian Court from subsuming the facts under the category of crimes against humanity because Chile, the country requested for the extradition (where Fujimori was arrested) did not envisage it in its legal system. The classification under ordinary criminal offences may therefore appear as a mandatory decision, which the simple declaration of their nature as international crimes is somehow intended to compensate for.

But one might also argue that, aside from that circumstance, the Peruvian Supreme Court has not ventured into the consequences that the attribution of this nature could have, because it simply did not need to. The events for which the former President of Peru is being tried occurred in the decade between 1990 and 2000 and do not pose the time barring problems that do affect the crimes perpetrated under the dictatorships of the other Latin American countries, which date back to the 1970 and 198 os. Regarding the amnesty laws, moreover, the IACtHR and subsequently the Peruvian Constitutional Court had already declared them invalid when the first ruling was handed down in the Fujimori case, on the grounds that they were contrary to the American Convention on Human Rights (ACHR) and the Constitution, ${ }^{42}$ respectively.

The declaration of the international criminal nature of the facts in the Fujimori ruling seems to serve then, rather, to underline the extreme gravity of the crimes and to frame them in the peculiar context of systematic and massive violence that characterised that stage of Peruvian history. ${ }^{43}$ The classification of the facts as international crimes is not, here, the prelude to the

41 The judgement, in determining the specific penalty, mentions only 'the characteristics of the execution of the act, its planned logic' (para. 766). Likewise, a consideration addressed by Judge San Martín to the Prosecutor, according to which, given the international criminal nature of the acts in question, he could have requested the application of the maximum penalty provided for by the law ( 30 years' imprisonment, instead of the 25 years that were requested by the Prosecutor and finally imposed), remains without consequence (para. 764). IACtHR, Barrios Altos v. Peru, judgement, 14 March 2001 and Peruvian Constitutional Court, Vera Navarrete, Gabriel Orlando, 'extraordinary habeas corpus application' (case no. 27982004-HC/TC), 9 December 2004.

43 It has been suggested that the objective of this statement is to offer a contribution to the effective realisation of the 'right to truth': Luis Ignacio Sánchez Rodríguez and Javier Chinchón Álvarez, 'Algunas consideraciones jurídico-internacionales acerca de la sentencia de la sala Especial de la Corte Suprema de la República del Perú contra Alberto Kenya Fujimori Fujimori', 10 Revista de Estudios Jurídicos (2010), p. 16. These authors criticise the 
implementation of the corresponding exceptional regime, but rather a key to interpreting a declaration with a marked symbolic and didactic function. ${ }^{44}$

Something similar occurs in the ruling of a Guatemalan Court of Appeals in the case of the Río Negro massacre: despite classifying the facts as an ordinary crime of murder, it, so to speak, calls out the Prosecutor for not having proposed the labelling of the facts as genocide, which would have better reflected the phenomenology of the acts. At the same time, since it is limited by the procedural obligation to rule only on the allegations presented by the appellants (Article 421 of the Guatemalan Criminal Code), the Court can do nothing more than declare in the legal reasoning that these facts could have constituted genocide, without reiterating this in the operative part. ${ }^{45}$

The same dual classification method also appears in Colombian case law. The Supreme Court of Justice of that country, in the Pérez García case, has convicted the defendant for homicide and bodily harm, but clarified, in the reasoning, that for a correct appreciation of their magnitude one must resort to the category of crimes against humanity, highlighting 'the systemic and general nature of the attack as criteria differentiating between an ordinary offence and a conduct that at the level of macro criminality affects human rights in an extreme way' 46

The court also expressly refers to the above-mentioned Fujimori judgment, identifying it as a precedent for the application of this dual classification of the facts. And it is interesting that the Colombian Supreme Court explains that this has 'the objective of remedying decisions that are formally correct but materially unjust, resorting to fundamental formulas that find in human rights philosophy a principle of material assessment of criminal unlawfulness' ${ }^{\prime} 7$

classification of the facts chosen by the Court, stating that it 'meekly embraces the rigid interpretation of the principle of criminal legality' (p. 14, free translation).

44 On the symbolic function of procedural expression in criminal trials involving international crimes, see, also for further references, Carsten Stahn, Justice as Message. Expressivist Foundations of International Criminal Justice (Oxford University Press, Oxford, 2020), p. 258 et seq.

45 Mixed Regional Chamber of the Court of Appeals of Cobán (Alta Verapaz, Guatemala), Macaro Alavarado Toj et al ('Masacre de Río Negro'), Judgement 96/2008 (process 89-2008-Of, 4th Chamber), 24 September 2008, point II of the reasoning. The massacre was committed in 1982 in the village of Río Negro by military and paramilitary groups claiming to be acting under the cover of the fight against the insurgent movements. More than 400 Maya Achi were killed, raped and tortured, and children were abducted and enslaved.

46 Colombian Supreme Court (Corte Suprema de Justicia), Criminal Cassation Chamber, $C$. Pérez García (no. 33118), Judgement, 15 May 2013, p. 25.

47 Ibid., p. 3 o. 


\subsection{The Effects: a Settlement of the Interests at Stake}

From the examples described, one may see that this hermeneutic exercise makes it possible to combine the demands faced in the above-mentioned dilemma. Thus, the classification of the facts as international crimes allows, first, removal of impediments to the prosecution and punishment of those responsible for the illegal acts and, second, an adequate reflection of their magnitude. The application of ordinary offences, on the other hand, serves to complement International Criminal Law, ${ }^{48}$ as they were already defined in national legislation when the events took place, and they also provide a sanctions framework that international normative sources (either conventional or customary) do not. This solves the objections of violation of the principles of non-retroactivity and legality of criminal offences and penalties.

Therefore, in this combination of applicable sources, the domestic category is used for the description of the elements of the crime and, normally, for the determination of the corresponding sanctioning framework. The international category, for its part, can fulfil two different functions: on the one hand, it can allow the application of the special regime for international crimes and thus overcome the obstacles to criminal prosecution arising from statutes of limitation and amnesty provisions, or it can allow the exercise of universal jurisdiction. On the other hand, it makes it possible to reflect the magnitude of conduct, the particular gravity and widespread nature of which would not be adequately reflected in the corresponding ordinary offence.

The courts therefore perform a 'primary classification of the definition of the crime and punishment', under national rules, and a 'secondary classification of categorisation' under international rules. ${ }^{49}$

The final product is a new description of a crime that has been effectively described as a 'Janus face. ${ }^{50}$ It has on the one side the ordinary offence and on the other side the international crime simultaneously and in combination. This overcomes the objections concerning non-compliance with the fundamental principles of Criminal Law and at the same time avoids the situation of impunity that would be generated by ordinary criminal rules in such exceptional contexts. In simple terms, the advantages of classification under each of the applicable criminal categories are exploited and their problems overcome.

48 Parenti, supra note 3, p. 504.

49 E. Malarino, 'Argentina', in K. Ambos (ed.), Desaparición forzada de personas. Análisis comparado e internacional (Temis, Bogotá, 20o9), 5-36, p. 25.

50 J.L. Guzmán Dalbora, 'The Treatment of International Crimes in Chilean Jurisprudence: A Janus Face', 10 International Criminal Law Review (2010) 535-547. 
The interpretative strategy of the dual classification achieves, as has been said, a settlement of the interests at stake that is undoubtedly positive. ${ }^{51}$ Nonetheless, a closer look reveals certain methodological flaws and problems of incompatibility with fundamental principles and guarantees of Criminal Law.

\subsection{Methodological Inconsistencies}

The classification of a fact as a crime, which is essential for the application of criminal law and its consequences, follows a defined order according to which the judge looks for the correspondence between the concrete fact, with all the elements that are manifested in it, and a legislative provision that typifies a specific offence. ${ }^{52}$ Once this correspondence has been found, from which the type of offence and the abstract penalty framework applicable to the case are derived, further factors can be taken into account, such as defences and aggravating or mitigating circumstances, which can in turn have an impact on the determination of the specific penalty. The identification of the offence under domestic criminal law should therefore be the first and essential step in this exercise.

The dual classification technique involves a kind of inversion of this logical order, or at least an anomaly in its use. After finding a correspondence between the concrete facts and the constitutive elements of an international crime (which allows for the applicability of the corresponding special punishment regime), a step backwards is taken, seeking in the domestic legal system a more solid normative support, more in line with criminal principles and, above all, one that provides the element that the international norm completely lacks, i.e., the sanctioning framework. ${ }^{53}$ This alters the order normally followed by the process of deciding whether the facts can be classified as a crime.

51 A positive opinion of the technique is shared by authors such as Parenti, supra note 3; Ollé Sesé, supra note 5 , p. 179.

$5^{2}$ See the first systematic study about this interpreting process, identifying the concepts of 'Tatbestand' (figura delictiva, fattispecie) and 'Typus' (tipo penal, tipo penale) as the key elements for the interpretation and application of Criminal Law in Continental legal tradition: W. Hassemer, Tatbestand und Typus: Untersuchungen zur strafrechtlichen Hermeneutik (Heiman, Köln, 1968).

53 See, e.g., FCTC of Posadas, Herrero, Carlos Omar about illegitimate deprivation of liberty (Case No. 87/2010), Judgement no. 1629, 16 August 2012, II issue, I(3): 'it is essential—for the purposes of its punishment-to subsume the harmful results produced by crimes against humanity into the categories of crimes under domestic law' (free translation). The judgement qualifies the facts both as crimes against humanity, declaring the inapplicability of statutory limitations, and as ordinary offences of illegal deprivation of liberty and ill treatment, applying the corresponding sanctioning frameworks. 
Secondly, this technique consists, in essence, of the purely jurisprudential creation of a new criminal category, which does not correspond exactly to either the international crime or the ordinary offence, but needs both to reflect all the constitutive elements and the applicable sanction. Crimes charged using this technique are thus characterised by 'incomplete legality'.54

In addition, the joint application of the two types of crime suffers from another methodological flaw, namely, the lack of a clear determination of the relationship between the two. ${ }^{55}$ In this respect, some judgements limit themselves to detecting the correspondence of the concrete facts with both criminal categories (the national and the international) simultaneously, considering them to be equivalent. They do not seem to consider that international crime requires the concurrence of at least one additional element (the so called international or contextual element). ${ }^{56}$

Other decisions describe, more correctly, the legal relationship between the two categories applied as a special (or 'inclusive') ${ }^{57}$ relationship, in which the ordinary offence provided for in the domestic system is the genus, and the international crime is the species. ${ }^{58}$ The latter presents all the elements of the genus plus a specific additional element, which coincides here with the international element, whose function is precisely to mark the distinction between ordinary crimes and international ones (as well as to distinguish between the different international crimes, when a conduct can represent several of them). Moreover, in several cases the specificity of the international crime with respect to an ordinary offence is also due to other constitutive elements that make up the underlying conduct. For example, the forced disappearance

54 Malarino, supra note 49, pp. 32-34.

55 Parenti, supra note 3, pp. 504-505: the author, despite favouring the dual classification technique, considers a clarification of this aspect to be essential for its correct application.

$5^{6}$ Moreover, one may recall that in many cases the differences between the structure of a crime under International Law and its definition under domestic legislation go beyond the contextual element: for instance, genocide as defined in several national legal systems encompass further protected groups, other than the four envisaged in the international norms (E. Santalla Vargas, 'An Overview of the Crime of Genocide in Latin American Jurisdictions', 10 International Criminal Law Review (2010) 441-452). The same can be predicated as to crimes against humanity (Emanuela Fronza, 'La réception des crimes contre l'humanité en droit interne', in M. Delmas-Marty et al., Les crimes contre l'humanité, 2nd ed. (PUF, Paris, 2018), and especially as to the definition of the conducts of torture and forced disappearance of people (Maculan, supra note 8, pp. 63-70).

57 Parenti, supra note 3, p. 505.

$5^{8}$ 'There is no doubt that the crime of illegitimate deprivation of liberty contains a description that is sufficiently broad to also include, in its generality, those specific cases of deprivation of liberty that are called "forced disappearance of persons": Argentine Attorney General's Office's 'Opinion' in the Simón case, supra note 27, para. IX(9) (free translation). 
of persons as a crime against humanity differs from the ordinary offence of abduction of persons not only because it must be committed in the context of a widespread and systematic attack against the civilian population, but also because its structure requires, in addition to the deprivation of liberty of the passive subject, the refusal to provide information on his or her whereabouts. ${ }^{59}$

Obviously, judges must verify in a timely manner the concurrence in the specific case of the contextual or international element, as with all other constitutive elements of a crime. However, this exercise is omitted on several occasions by the courts, which seem to take for granted the equivalence between the international crime they are applying and the ordinary offence that is closest to it. ${ }^{60}$

Beyond the controversial and sometimes deficient identification of the special elements of international crime with respect to the common offence under national legislation, the special relationship between these categories would represent a case of apparent concurrence of norms.$^{61}$ In accordance with the criteria that Continental legal systems provide for this situation (concurso de leyes, Gesetzeskonkurrenz/-einheit, concours apparent, concorso apparente), only the most specific type of crime should be applied, i.e., the lex specialis, on the understanding that this already incorporates the most generic crime. ${ }^{62}$

59 Some decisions underline also the different legal interests protected by the two crimes, which for the common crime of kidnapping of a person is personal freedom, while for forced disappearance comprises a set of legal interests, including personal freedom, physical and psychological integrity, the right to access to justice and to an effective remedy and the right to life: Colombian Constitutional Court, C-317/2002 Judgement, 2 May 2002, chapter VI, para. 2(d); Peruvian National Criminal Court (Sala Penal Nacional), Ernesto Castillo-Páez, Trial against Jiménez del Carpio and other for kidnapping of Ernesto Rafael Castillo Páez, (case no. 111-04), 2o March 2006, para. 7 of the 'considerations on the legal qualification'.

6o Parenti, supra note 3, p. 506, highlights the importance of a specific verification, by judges, of the concurrence of the contextual element of the international crime category to be applied, and offers as an example of this 'virtuous practice' a sentence of the Federal Court of Appeals of Buenos Aires (Amarante case, 29 November 2005).

61 As correctly pointed out in Argentine Attorney General's Office's 'Opinion' in the Simón case, supra note 27 , para. $\mathrm{IX}(9)$.

62 The principle lex specialis derogat legi generali is expressly provided in several Continental legal systems (Article 8 Spanish Penal Code (PC); Article 15 Italian PC) or applied as a consolidated criterion in jurisprudence and scholarly literature (in Germany and France), and it has been recognised as a general principle of law: see the comparative overview offered by K. Ambos, Treatise on International Criminal Law. Volume II: The Crimes and Sentencing (Oxford University Press, Oxford, 2014), pp. 248-289; C.F. Stuckenberg, 'Multiplicity of Offences: Concursus Delictorum', in H. Fischer, C. Kress and S.R. Lüder (eds.), International and National Prosecution of Crimes Under International Law (Nomos, Berlin, 2001), 559 et seq., pp. 587-588. 
However, when courts use the dual classification method, they do not select either the ordinary or the international offence, as the principle of lex specialis requires, but apply both together. If this were not the case, they would be faced with an incomplete or useless normative provision. Useless, in the case of the domestic law, because it was in force at the time of the events and fulfils the mandate of determining the conduct and the punishment, but it would lead to the exclusion of criminal responsibility due to statutory limitations or to the effect of an amnesty provision. Incomplete, in the case of the international norm, because it does not provide a framework for punishment and does not even offer a comprehensive description of the criminal conduct.

If, in order to avoid this impasse, the technique of dual classification proposes the combined application of the two rules, it must be admitted that the relationship between them is not, as is often claimed, one of specialty, or that it is not in any case subject to the discipline of the apparent concurrence of norms. A correct application of the dual classification would then require, at the very least, a more detailed study of this relationship and of the applicable penalty regime.

\subsection{Challenges to the Principles of Legality and Non-Retroactivity}

Aside from the inconsistencies raised by dual classification from a methodological point of view, this approach also conflicts with fundamental principles in the criminal law field. By applying to the facts a category (crimes against humanity) that was not provided for in the domestic legislation when these illicit acts were committed, doubts are raised about the compatibility of this classification with the principles of legality and non-retroactivity (the latter being, in fact, a part or subprinciple of the former, ${ }^{63}$ so from now on we will refer to both in the singular).

After summarising the various conceptions of the principle within the international sphere and the national systems in question, this section will offer an analysis of the reasoning of Latin American case law to overcome this apparent obstacle and possible criticisms thereof.

\subsection{1}

International Principle of Legality vs. Domestic Principle of Legality?

The principle of legality is a fundamental pillar of any modern criminal law system and at the same time instrumental to the protection of the rule of law, the equality of citizens before the law and the legitimacy of punitive

63 Gallant, supra note 18, p. 241 et seq. 
intervention. ${ }^{64}$ It is recognised in some of the most important international instruments for the protection of human rights, ${ }^{65}$ which, using different terminology, establish the demand of specificity, the prohibition of retroactivity and of analogy in malam partem. ${ }^{66}$ Its recognition is now so broad and consolidated that legality has been affirmed as a peremptory norm. ${ }^{67}$

Nonetheless, the determination of its concept and scope in the specific field of International Criminal Law is a much debated and probably unsolvable issue. On the one hand, this branch of law is a product of the fusion of horizons between the Continental and common law systems, in which the principle of legality is conceived in a different way. While the Anglo-Saxon systems admit unwritten sources, such as case law and custom, as criminalising rules, the systems of the Continental tradition (among them, the Latin American systems on which this study is based) interpret it in a more demanding and 'robust' way, ${ }^{68}$ requiring that the criminalising rules and penalties be laid down in written laws, formally approved by Parliament (the so-called reservation of law). Furthermore, the guarantee function, which in Romano-Germanic systems is performed by the mandates of determination and precision and the prohibition of retroactivity, is pursued in common law countries by the mechanism of binding precedent or stare decisis which, by giving binding effect to precedent

64 Ibid., p. 11 et seq.; Ferdinandusse, supra note 4, p. 222 et seq.

65 Article 7 European Convention of Human Rights (ECHR); Article 15 International Covenant on Civil and Political Rights (ICCPR); Article 11(2) Universal Declaration of Human Rights; Article 7 African Charter of Human Rights; Article 9 ACHR; Article 15 revised Arab Charter on Human Rights; Article 99 of the 1949 III Geneva Convention; Article 75(4)(c) I Additional Protocol to the Geneva Conventions; Article 6(2)(c) iI Additional Protocol to the Conventions.

66 Gallant, supra note 18, p. 156 et seq.

67 At least, in the more limited and flexible version of the principle described in this section, following an evolution that began with World War II: Gallant, supra note 18, p. 38 et seq. The author reaches this conclusion after a very extensive comparative analysis of domestic legislation, international treaties and the practice of international courts. Another comparative study (of a much more limited scope) comes instead to the conclusion that 'there is an erratic and inconsistent application of the PLP (principle of criminal legality)': J. Dondé Matute, Principio de legalidad penal: perspectivas del derecho nacional e internacional (Bosch, Barcelona, 2007), p. 316 (free translation).

68 This 'stronger' version of the principle of legality has not become a rule of international custom: Kenneth Gallant, 'Legality as a rule of international customary law: the nonretroactivity of offences and penalties', in J.P. Montiel (ed.), La crisis del principio de legalidad en el nuevo Derecho penal: ¿Decadencia o evolución? (Marcial Pons, Madrid, 2012), pp. 317 and 329. These structural differences between the main legal traditions are not so clear-cut, anyway, since even those domestic systems 'that profess respect for the principle of legality may well admit various exception to its application, thereby diluting its actual force and finding a balance between certainty and flexibility': Grover, supra note 4, p. 135. 
case law, obliges judges to apply the decisions issued by the same or other (higher) courts in similar cases. ${ }^{69}$

On the other hand, International Criminal Law is also the product of the combination of two legal branches, Criminal Law, and International Law, in which the principle takes on a very different content. ${ }^{70}$ Firstly, in International Law there is no reference to the corollary of reservation of law, that is, to the political or democratic aspect of the principle of legality. ${ }^{71}$ This is due both to the absence at the international level of a legislator as such and of a Montesquieustyle separation of powers, and to the inclusion of various legal traditions, as recalled above. ${ }^{72}$ In this area, the concept of 'criminal legislation' is replaced by a broader concept of 'law'. ${ }^{73}$ This covers not only written sources, but also

69 The possibility of departing from precedents is limited to situations in which the interpreter considers that the jurisprudential solution no longer reflects social reality (overruling) or to cases that have important differences from those already resolved in the past (distinguishing). For a comparative study of this principle in the main legal traditions, J. Correcher Mira, Principio de legalidad penal: ley formal vs. Law in action (Tirant lo blanch, Valencia, 2018), pp. 179-530 and 583 et seq. In more recent times, the doctrine of void for vagueness, which determines the invalidity of any legislative provision that does not meet minimum standards of clarity and precision, has been gradually affirmed in common law systems: see, among others, A.E. Goldsmith, 'Void-for-Vagueness Doctrine in the Supreme Court, Revisited', 3o American Journal of Criminal Law (2002-2003), p. 279 et seq.

70 Grover, supra note 4, pp. 102-105.

71 It is precisely this argument that leads Argentine judge Schiffrin to conclude, in relation to the request for extradition of a Nazi criminal, that the principle of legality makes no sense in the international sphere, since its sole purpose is, in his view, to guarantee the separation of powers (Federal Court of Appeals for Criminal and Correctional Matters of La Plata, Schwammberger case, Decision on extradition, 30 August 1989, paras 32-33). The judge even stated that this principle would end up playing a role in the international sphere contrary to its original purpose, contributing to oppression instead of protecting against it (para. 33). In my view, this interpretation is objectionable, firstly because it seems to forget the material dimension of the principle which, as will be seen below, does have a place in the international sphere, and secondly because it appeals to a kind of supposed teleological interpretation of the principle but ends up completely distorting it.

72 A. Gil Gil, 'La excepción al principio de legalidad del n. ${ }^{\circ} 2$ del artículo 7 del Convenio Europeo de Derechos Humanos', 63(1) Anuario de Derecho penal y Ciencias penales (2010) 131-163, pp. 143-145. M. Scoletta, 'El principio de legalidad penal europeo', in L.M. Díez Picazo and A. Nieto Martín (eds.), Los derechos fundamentales en el derecho penal europeo (Civitas, Madrid, 2010) 245-291, attributes this exclusion to the procedural nature of the principle of reservation of law, which is strongly conditioned by the historical-constitutional frameworks of reference.

73 Whereas in English the word 'law' normally refers to both concepts, other languages express the difference between them also in terminology: the Latin dichotomy lex/ius can also be found in Spanish (ley/derecho), German (Gesetz/Recht), French (loi/droit), Italian (legge/ diritto). The second term, which is wider than the former, is the one used in both Article 7 ECHR and Article 9 ACHR. 
general principles of law and, as the European Court of Human Rights (ECtHR) has clarified, case law. ${ }^{74}$

Secondly, in the international sphere, the material-liberal dimension of the principle remains intact, providing conditions and limits to protect citizens against possible abuses of punitive power. This function as a guarantee has been interpreted, especially by the ECtHR, as a requisite of accessibility and predictability of criminal law. ${ }^{75}$ These concepts, despite their different

74 ECtHR, The Sunday Times v. UK, Judgement, 26 April 1979, paras 47-48; S.W. v. UK, Judgement, 22 November 1995, para. 35; Pessino v. France, Judgement, 10 October 2006, para. 29, and the fundamental Contrada v. Italy, Judgement, 14 April 2015, para. 69, among others. For a commentary, see: William Schabas, The European Convention on Human Rights. A Commentary (Oxford University Press, Oxford, 2015), p. 328 et seq.; S. Huerta Tocildo, 'The weakened concept of the European principle of criminal legality (Article 7 ECHR and P7-4)', in F.J. García Roca and P. Santolaya Machetti (ed.), Europe of rights: a compendium on the European convention of Human Rights (Brill, Leiden, 2012), 315-336; Correcher Mira, supra note 69, p. 557 et seq. The IACtHR, on the other hand, has not had the opportunity to rule on this point, although it has de facto admitted the retroactive application of the unfavourable jurisprudence that it has created: see Marina Mínguez Rosique, "The principle of legality in criminal law in the Inter-American System for the Protection of Human Rights', in M. Pérez Manzano, J. Antonio Lascurain Sánchez and M. Mínguez Rosique (eds.), Multilevel protection of the principle of legality in criminal law (Springer, Berlin, 2018), 97-119. The extension of the prohibition of retroactivity to jurisprudence, beyond legislation, has recently been maintained by some national courts in Continental legal systems: for example, by the Italian Constitutional Court, in its 'twin' judgements, Nos 348 and 349, respectively, of 22 and 24 October 2007 (see Massimo Donini, Europeismo giudiziario e scienza penale. Dalla dogmatica classica alla giurisprudenza-fonte (Giuffrè, Milano, 2011), pp. 92-102). The German Bundesverfassungsgericht has also expressed the same position: BVerfG, 2 BvR 2559/o8, Judgement, 23 June 2010: see Lothar Kuhlen, 'Sobre la relación entre el mandato de certeza y la prohibición de la analogía', in J.P. Montiel (ed.), La crisis del principio de legalidad en el nuevo Derecho penal: Decadencia o evolución (Marcial Pons, Madrid, 2012), 169-172. Manes describes the acceptance of this broader scope of the principle of non-retroactivity as the most evident example of judicial transplant from European to national jurisprudence: V. Manes, 'I principi penalistici nel network multilivello: trapianto, palingenesi, crossfertilization', 3 Rivista Italiana di Diritto e Procedura Penale (2012) 839-874. Other scholars are instead very critical of the role that the ECtHR assigns to jurisprudence, considering that it implies a complete abandonment of the principle of legality in its formal aspect, of its democratic inspiration and of the specificity component: Huerta Tocildo, supra in this same note. In my opinion, this position does not consider the possible positive effect implied by the extension of the principle of legality (more precisely, of the criteria of accessibility and predictability) to sources that, de facto, concur with legislation to create the penal norms finally applied to concrete cases.

75 See, inter alia, ECtHR, Sunday Times v. UK, Judgement, 26 April 1979, para. 49; Kokkinakis v. Greece, Judgement, 25 March 1993; S.W. v. UK and C.R. v. UK, both Judgements of 22 November 1995, para. 36; Cantoni v. France, Judgement, 15 November 1996, para. 86 et seq.; Pessino v. France, Judgement, 10 October 2006, para. 29; Kafkaris v. Cyprus, Judgement, 
articulation, are in fact conceived as 'functional equivalents' ${ }^{\text {'6 }}$ of the mandate of determination and the prohibition of retroactivity. ${ }^{77}$ Similarly, the IACtHR requires 'that the punitive norm exists and is known or can be known' ${ }^{78}$

Insofar as these requirements apply to criminal law in the broad sense, i.e., irrespective of the formal nature of the normative act ${ }^{79}$, the scope of the safeguard is increased, since in this way the prohibition of retroactivity also covers judicial interpretation, both in the case of a new interpretation of an 'obscure' rule and in the case of an unfavourable and unforeseeable change in case law. ${ }^{80}$

12 February 2008, para. 139 et seq.; Del Río Prada v. Spain, Grand Chamber Judgement, 21 October 2013, para. 91 et seq.

76 Scoletta, supra note 72, p. 252. In particular, the application of these concepts in a synchronic perspective makes them an equivalent of the prohibition of analogy, while in a diachronic perspective they represent an alternative to the prohibition of legislative amendment and retroactive interpretation in malam partem: V. Valentini, Diritto penale intertemporale: logiche continentali ed ermeneutica europea (Giuffré, Milano, 2012), pp. 103-104.

77 Despite the fact that some authors have accused them of being too broad or too flexible (Andreana Esposito, Il diritto penale 'flessibile'. Quando i diritti umani incontrano i sistemi penali (Giappichelli, Torino, 2008), p. 381 or of difficult realisation (J. Landa Gorostiza, 'Ejecución de penas y principio de legidad ante el TEDH', 4 InDret (2O12) 4-28, p. 9). The ECtHR's understanding of the criterion of foreseeability leads to its extension in several senses: its object is not necessarily the penalty, but the risk of it; a subjective perspective is accepted and cases in which foreseeability would have required legal aid are included (J.A. Lascurain Sánchez, 'How judges are bound by the legal definition of the crime', in M. Pérez Manzano, J.A. Lascurain Sánchez and M. Mínguez Rosique (eds.), Multilevel protection of the principle of legality in criminal law (Springer, Berlin, 2018), pp. 55-73). Valentini warns that, since the criterion of predictability is so indeterminate, the more the range of parameters to be taken into account is extended, the more the possibilities of censoring the hermeneutic epilogue are reduced (Valentini, supra note 76, p. 138).

78 IACtHR, De la Cruz Flores v. Peru, Judgement, 18 November 2004, para. 104. It is curious how the IACtHR has emphasised the importance of the principle of legality, and of the judge's strict compliance with the criminal law (ibid., para. 82; García Astoy Ramírez Rojas v. Peru, Judgement, 25 November 2005, para. 190; Liakat Ali Alibux v. Suriname, Judgement, 20 January 2014, para. 61), but at the same time gives the impression that it does not feel itself to be the addressee of its own doctrine, when it has to decide about serious human rights violations: Mínguez Rosique, supra note 74, p. 110.

79 Gil, supra note 72 , p. 145, criticises this conversion of the principle of reservation of law as weakening the guarantee dimension of the principle of legality. Gallant, on the other hand, proposes accepting that common law and customary law can fulfil the objectives of the principle of legality, thus converting the well-known motto created by Feuerbach into the new motto nullum crimen, nulla poena sine iure: Gallant, supra note 18, p. $35^{2}$ et seq.

8o The ECtHR dealt with this issue in the Del Río Prada v. Spain case, which condemned Spain for the violation of Article 7 ECHR (principle of legality) in relation to the so-called 'Parot doctrine', developed by the jurisprudence of the Supreme Court, which had contra reum effects for the determination of time limits for serving a sentence (ECtHR, Del Río Prada v. Spain, Judgement, 10 July 2012, confirmed by the Grand Chamber, Judgement, 21 October 
However, this interpretation has also had the opposite effect of limiting the strength of the safeguard of legality: on the one hand, it has made it possible to save vague legal provisions, provided that the judicial interpretation clarifying them, also with contra reum effect, is reasonably foreseeable. ${ }^{81}$ On the other hand, with regard to the prohibition of non-retroactivity, it has deemed it sufficient that the unlawful conduct was prohibited, at the time of its commission, by general principles of law, even if it was not defined as such in the

2013). For a commentary, see S. Huerta Tocildo, 'The annulment of the Parot Doctrine by the European Court of Human Rights. ECtHR judgement of 21 October 2013: much ado over a legally awaited judgement', in M. Pérez Manzano, J.A. Lascurain Sánchez and M. Mínguez Rosique (eds.), Multilevel protection of the principle of legality in criminal law (Springer, Berlin, 2018), 141-157. The same idea that the principle of non-retroactivity reaches unfavourable judicial interpretations is shared by the Corpus Iuris drafted for the European Union by a Group of Experts, which establishes that 'les changements d'interpretation ne sont admissibles que s'ils étaint raisonnablement prévisibles': M. Delmas-Marty (ed.), Corpus Juris, on criminal provisions for the protection of the European Union's financial interests (Economique, Paris, 1997), 'principes directrices'. Some authors have criticised this extension of the principle of non-retroactivity to case law, considering that it implicitly equates the legislator, democratically legitimised to create criminal rules, with the judge, who does not enjoy this legitimisation: Huerta Tocildo, supra note 74. In my opinion, these criticisms are based on a mystified view of the process of creating the criminal norm, which does not take into account the fact that judicial interpretation normally participates in the construction of the criminal norm (as an entity distinct from the legal provision). Perhaps the doubts raised in this regard by a Spanish scholar are more accurate: in addition to questioning what jurisprudence the principle of legality should refer to (a single decision by any court, or only one decision by the Supreme Court, or a consolidated line of interpretation...), he highlights the possible perverse effects of this principle. Thus, on the one hand, the author points out that it would generate a possible incentive for the judges, knowing that they only bind themselves by choosing an interpretation favorable to the defendant (while they will always be able to alter a less favorable interpretation), to choose now the hardest interpretation among those reasonably possible; on the other hand, the legislator himself could find an incentive to harden the law and avoid the effects of the favourable interpretation when these do not suit him politically: J.A. García Amado, 'On the principle of criminal legality and its scope: foreseeability as a component of legality', in M. Pérez Manzano, J.A. Lascurain Sánchez and M. Mínguez Rosique (eds.), Multilevel protection of the principle of legality in criminal law (Springer, Berlin, 2018), 177-193. Although these risks cannot be completely excluded, I doubt that the judge's concern not to be tied down in the future prevails over the objective of guaranteeing a 'just' sentence, in the sense of material justice, especially in cases involving the atrocious crimes that this paper deals with. Regarding the second risk, it seems to me that the legislator (both the Spanish one and those of other legal systems) already shows a clear tendency towards the hardening of sentences, institutes, and treatments for certain types of crimes (among them, the crimes of terrorism and international crimes), and that the virtual imposition of the prohibition of unfavorable retroactivity to the jurisprudence would not increase this tendency significantly.

81 ECtHR, Cantoni v. France, supra note 75, para. 33 et seq. See also A. Cassese, Cassese's International criminal Law (Oxford University Press, Oxford, 2013), pp. 31-32. 
legislation. ${ }^{82}$ This diachronic (backward) extension of punitive intervention has made it possible to reduce, traditionally, at European level, the need for recourse to the exception clause formulated in Article $7(2)$ of the European Convention of Human Rights (ECHR). ${ }^{83}$

It is precisely the provision of a clause derogating from the principle of legality that is the third specific element of its definition in the international sphere. Such clause expressly provides for its relaxation in relation to the most serious human rights violations that can be qualified as international crimes. ${ }^{84}$ Both Article 7(2) ECHR and Article 14(2) ICCPR recognise that the principle, affirmed in general terms by the corresponding first sections, does not prevent the prosecution and conviction of conducts which, at the time of their

82 This is clearly stated in ECtHR, Kononov v. Latvia, Judgement, 17 May 2010, concluding that in 1944 (when the events occurred) the war crimes for which the applicant (a partisan who had fought against the Nazis) had been convicted were defined with sufficient accessibility and predictability not by Latvian criminal law, but by a set of international sources, mainly the Hague Conventions of 1907 (even though Latvia had not ratified them). See E. Fronza and M. Scoletta, 'Corti regionali, crimini internazionali e legalità penale: spunti (e problemi) a partire dal caso Kononov', 1(1) Jusı@@unibo.it (2012) 87-105. Inter-American jurisprudence has not affirmed this so clearly, but some scholars understand that the 'applicable law' referred to in Article 9 ACHR includes both domestic law and international law (J.L. Guzmán Dalbora, 'El principio de legalidad penal en la jurisprudencia de la Corte Interamericana de Derechos Humanos', in K. Ambos, E. Malarino and G. Elnser (eds.), Sistema Interamericano de Protección de los Derechos humanos y Derecho penal internacional. Vol. I (Konrad Adenauer Stiftung, Montevideo, 2010), 178-179; S. García Ramírez and J. Morales Sánchez, 'Consideraciones sobre el principio de legalidad penal en la jurisprudencia de la Corte Interamericana de Derechos Humanos', 24 Cuestiones constitucionales. Revista mexicana de Derecho constitucional (2011) 195-246, p. 221), with the consequence that it would be possible to punish a crime not defined in the national system, if it was foreseen as a crime under international law at the time of its commission (Mínguez Rosique, supra note 74, p. 97).

83 One can find an example in the ECtHR judgements $W$. v. Germany and Streletz, Kessler and Krenz v. Germany, both of 22 March 2001, in which the practice in the Eastern Germany of justifying the shooting of those trying to climb the Berlin Wall was considered contrary to international law. This trend seems to change in the Kolk and Kisliyiy v. Estonia case, Judgement, 17 January 2006, where the Court applies the exception clause of Article $7(2)$ ECHR in a declared manner (on which, see below in this same section).

84 Although some authors have tried to show that Article 7, paragraphs 1 and 2, express the same rule with regard to the principle of legality, and that the second paragraph only expands the number of sources of incrimination (A. Cassese, 'Balancing the Prosecution of Crimes against Humanity and Non-Retroactivity of Criminal Law: the Kolk and Kislyiy v. Estonia case before the ECHR', 4(2) Journal of International Criminal Justice (2006) 410-418), I share the majority view that this clause is a derogation from the general principle established by paragraph 1: see, also for further references, T. Mariniello, 'The "Nuremberg Clause" and Beyond: Legality Principle and Sources of International Criminal Law in the European Court's Jurisprudence', 82 Nordic Journal of International Law (2013) 221-248, pp. $227-228$. 
commission, 'constituted an offence according to the general principles of law recognised by civilized nations' ${ }^{\prime 85}$ or 'by the community of nations'. ${ }^{86}$ In other words, limited to this category of illegal acts, the simple provision in unwritten normative sources ${ }^{87}$ is considered sufficient, provided that the conduct in question is compatible with the 'essence' of the crime charged. ${ }^{88}$

This clause was in factintroduced to prevent the legitimacy of the Nuremberg trials from being questioned (hence the name 'Nuremberg clause'), and it has been applied by the ECtHR on very few occasions, usually in relation to crimes committed during the Second World War, ${ }^{89}$ albeit with some exceptions. ${ }^{90}$

Latin American legal systems in which the judgments analysed have been issued, on the contrary, clearly understand, in accordance with the Continental legal tradition to which they belong, the principle of legality in its strictest guise. All of them envisage the principle of legality in their constitutional text, stressing the requirement that crimes and penalties be provided for by a legislative act prior to the commission of the offences and the imposition of the sentence. ${ }^{11}$ They therefore recognise, with constitutional hierarchy, the

85 Article $7(2)$ ECHR.

86 Article 14(2) ICCPR. The American Convention, on the other hand, does not contain such a clause.

87 It is not surprising that Germany, when ratifying the ECHR, initially made a reservation to this paragraph, considering it incompatible with its Constitution (the reservation was subsequently withdrawn, in October 2001). Some legal systems have, however, introduced a rule that expressly allows the retroactive or retrospective application of the categories of war crimes and crimes against humanity: see Article 5(4) of the Latvian Penal Code, Article 5(3) of the Estonian Penal Code. Albania and Poland have introduced the same exceptional provision in their Constitutions (respectively, Article 29 and 42(1)): cf. Ferdinandusse, supra note 4 , p. 227.

88 M. Shahabbuddeen, 'Does the Principle of Legality stand in the Way of Progressive Development of Law?', 2 Journal of International Criminal Justice (2004), 1007-1017, p. 1017.

89 Mariniello recalls that the ECtHR applied Article 7(2) to cases of war crimes, treason and (since the case Touvier v. France, 29420/95, Plenary, 13 January 1997) crimes against humanity, leading to the declaration of inadmissibility of appeals alleging the violation of the principle of non-retroactivity: Mariniello, supra note 84, pp. 229-30. On the contrary, the ECtHR found a violation of Article 7 ECHR in the case Korbely v. Hungry, Judgement, 19 September 2008, in which the applicant was convicted of acts committed in the 1950s (outside the framework of Nazi crimes) based on a later law declaring it non-applicable.

90 ECtHR, Kolk and Kislyiy v. Estonia, supra note 83, which for the first time applies the exception clause outside the context of Nazi crimes (the events, qualified as crimes against humanity, had been committed in 1949). Ferdinandusse stresses that even the travaux préparatoires of the ECHR show that it was not the intention of the drafters of the Convention to limit the scope of the clause to cases relating to the Second World War: Ferdinandusse, supra note 4, pp. $233-234$.

91 Limiting ourselves to the legal systems from which the analysed jurisprudence has been extracted: Article 18 of the Argentine National Constitution; Article 19(3) of the Political 
formal aspect of the principle of legality (reservation of law), which requires that the incriminating norms be contained in a legislative source, approved by Parliament and in accordance with the legally established procedure, with the democratic guarantees that this ensures. The same principle is also reiterated in their Penal Codes, ${ }^{92}$ which in some cases add further elements to their content, such as the rule of retroactivity of favourable criminal law.

It is true that some of these Constitutions recognise the direct applicability of certain international normative sources. Thus, for example, Article 75(22) of the Argentine Constitution provides for the applicability, with constitutional hierarchy, of certain human rights treaties listed there, 'under the conditions of their validity'. However, the constitutional provision itself makes it clear that these treaties 'do not repeal any article of the first part of this Constitution and must be understood as additional to the rights and guarantees recognised by it': among them, the principle of legality contained in Article 18. Another constitutional provision that, as we have seen, ${ }^{93}$ has sometimes been used in the Argentine jurisprudence to argue the direct applicability of international custom is Article 118, which refers to offences 'against the law of nations'; however, this provision is in fact limited to setting out a jurisdictional criterion, and in any case, it should be balanced against Article 18, setting out the principle of legality. It is noteworthy also that Argentina has entered a reservation to Article 15(2) ICCPR, declaring that the application of the second part of it 'shall be subject to the principle laid down in Article 18 of the Argentine National Constitution'.94

In Colombia there is also a constitutional provision (Article 93) that gives direct effect, and even preference over national legislation, to 'international treaties and conventions ratified by Congress that recognise human rights and prohibit their limitation in states of emergency', further establishing that ' $[t]$ he rights and duties enshrined in this Charter shall be interpreted in accordance with the international treaties on human rights ratified by Colombia'. This provision is the basis on which the Colombian Constitutional Court has

Constitution of the Republic of Chile; Article 29(2) of the Political Constitution of Colombia; Articles 24(d) and 139(9) and 11 Political Constitution of the Republic of Peru. The Constitution of Uruguay, on the other hand, does not state the principle of legality as such, but it implicitly includes it in the principle of freedom stated in its Articles 10(2) and 72 .

Article 2 Argentine PC; Articles 1 and 18 Chilean PC; Article 6 Colombian PC; Articles 2, 6 and 7 Peruvian PC; Articles 1 and 15 Uruguayan PC.

93 Supra, section 2.1.

94 Ferdinandusse, supra note 4, pp. 71-76, who concludes that the question of direct application of international law as a criminalising norm has not been conclusively settled in the Argentine system. 
constructed the doctrine of the 'constitutional bloc', 95 which allows it to use as a parameter, when deciding on the constitutional legitimacy of a legislative provision, not only the Constitution, but also the rules of the international human rights treaties that the country has ratified. However, the constitutional provision limits its scope to treaty rules, without making reference to international custom. Moreover, in this case too, the same Charter enshrines, in its Article 29, the principle of legality, formulated in such a way as to clearly include the reservation of law. Thus, the possibility of interpreting it according to the broadest criterion admitted by some international instruments, so as to encompass customary sources as well, raises a conflict between constitutional principles.

In conclusion, even in those constitutional texts where an openness to international sources can be seen, it is doubtful that this provision implies the direct applicability of the latter to attribute individual criminal liability ${ }^{96}$ It can be said that the understanding of the principle of legality in the systems analysed is maintained in its 'robust' version, requiring that, in general, both criminal conduct and applicable penalties be provided for by legislative acts that exist prior to the commission of the acts.

The question is whether in these systems it is then possible to admit a different concept of the principle of legality, more flexible and closer to the international understanding, when the category of international crimes comes into play.

\subsubsection{Legal Reasoning and Critical Remarks}

The conceptual framework that has been briefly summarised shows the 'culture clash' between different branches of law and different legal traditions that Latin American courts face when judging past atrocities.

In order to classify the facts as international crimes, in the absence of the category in domestic legislation at the time the atrocities were committed, the judgements essentially appeal to international treaties. However, from the perspective of the Romano-Germanic tradition, the treaty rules, despite being lex scripta, do not provide a clear and precise determination of all the constitutive elements of the crime. By their very nature, these instruments contain only the prohibition of certain conduct that violates human rights. ${ }^{97}$ Moreover, the

95 R. Uprimny, El bloque de constitucionalidad en Colombia. Compilación de jurisprudencia y doctrina nacional e internacional (Oficina del Alto Comisionado de Naciones Unidas para los Derechos Humanos, Bogotá, 1991).

96 This conclusion is shared by Ferdinandusse, supra note 4, p. 26 et seq.

97 In similar terms I. Bantekas, International Criminal Law (Bloomsbury, Oxford/Portland, 2010), p. 22. 
fact that they impose an obligation on States party thereto to take all necessary legislative measures to criminalise the conduct prohibited in the international text suggests that the Convention 'does not establish any criminal offence in accordance with the requirements of the principle of legality, but rather describes the elements that the criminal offence must contain. ${ }^{98}$

But, above all, many of the international Conventions invoked by the courts in the judgements analysed were signed after the criminal acts judged in these proceedings occurred: this is the case of the 1994 Inter-American Convention on Forced Disappearance of People, and of the 2006 International Convention on Forced Disappearance of People, both approved long after the fall of the dictatorships that had systematically carried out this criminal practice. The same can be said of the ICC Statute, the only international instrument to date that defines the category of crimes against humanity as a whole. ${ }^{99}$ The application of the definitions of the crimes contained in these Conventions to acts committed before their entry into force in the national system in which the judging court operates constitutes, prima facie, a violation of the principle of non-retroactivity of unfavourable criminal law as envisaged in such domestic systems.

When faced with this predictable objection, the courts often use the argument that the treaty rules cited simply crystallise prohibitions contained in international custom, which did exist when the events occurred. The application of these conventions would therefore be 'retrospective and not retroactive'.100

Nevertheless, recourse to international custom as a source of incrimination in turn poses several challenges to the principle of legality. First, its application should be subject to prior verification that a customary rule prohibiting the conduct in question actually existed at the time of the events. But courts sometimes neglect this verification stage ${ }^{101}$ and uncritically assume that the

98 Dissenting vote of Judge Vasquez attached to the Argentine Supreme Court's ruling in the Arancibia Clavel case: Argentine Supreme Court, Arancibia Clavel, Lautaro on aggravated homicide and illicit association and others (case no. 259), Judgement, 24 August 2004, para. 29 (free translation).

The Draft Articles on Prevention and Punishment of Crimes against Humanity, adopted by the International Law Commission on 15 May 2019, apart for being still at a draft stage, adopt the same definition of the category contained in Article 7 of the Rome Statute. Sánchez Rodríguez and Chinchón Álvarez, supra note 43.

101 In the same vein, J. Pablo Montiel (ed.), 'La "mala costumbre" de vulnerar derechos humanos: análisis y pronóstico de la costumbre internacional como fuente de Derecho penal internacional', in La crisis del principio de legalidad en el nuevo Derecho penal: ¿Decadencia o evolución? (Marcial Pons, Madrid, 2012), 399-434, p. 414. 
normative corpus of international crimes dates back to the Nuremberg era, completely omitting more specific verification.

This is not a minor issue, because although the Nuremberg experience marked the origin of international crimes, the structure and content of this category has evolved a great deal since then. For example, the idea that in the $1970 s$ (the period of most intense State violence on the Latin American continent) there was an opinio juris and a consolidated practice of States regarding the definition of crimes against humanity as we know it today is disproved by the many transformations that this criminal category has undergone over the years. ${ }^{102}$ At that time, crimes against humanity had not yet been emancipated from the need for a link to an armed conflict, which was provided for in the Nuremberg Charter, nor was it specified that the conduct had to be committed in the context of a massive and systematic attack, as required today by the Rome Statute and the now consolidated customary definition of such crimes. ${ }^{103}$ Moreover, many of the underlying conducts that are now punished under this category were not expressly provided for at the time: foremost, the forced disappearance of persons. What can be said then is that, when these acts occurred, there was a common core of customary law prohibiting crimes against humanity, but the exact content of the category and its constitutive elements were not defined.

Even if it were to be shown that a valid customary rule defining the crimes existed at that time, international custom poses problems for the material guarantee of legal certainty. ${ }^{104}$ Its unwritten nature and progressive formation, as well as the plurality of the sources that contribute to it, impinge on its accessibility and make it very difficult for citizens to know in advance, with a satisfactory level of certainty, the exact content of the prohibited conduct and

The main changes in this evolution are the disappearance of the nexus with an armed conflict, the requirement of a massive or systematic attack against the civilian population, the elimination of the distinction between murder-type and persecution-type conducts, the expansion of the list of constitutive conducts: see, among others and for further references, Ambos, supra note 62, p. 46 et seq. Ibid., and Cassese, supra note 81 , pp. 105-8.

104 This was made clear by Judge Fayt in his dissenting opinion attached to the Arancibia Clavel judgement, supra note 98 (para. 42, last paragraph). Judge Vásquez in his dissenting vote attached to the same sentence also warns: 'This court cannot refrain from noticing the tension between States obligation to prosecute human rights violations, according to the current evolution of law, and the fact that the passing of time makes the statutory limitations applicable to the cases. Nontheless, it is dangerous for legal certainty and international coexistence to admit that jus cogens can establish criminal offences' (Judge Vásquez dissenting opinion, para. 32, free translation). 
the consequences that its commission entails. ${ }^{105}$ It is true that, if we speak of crimes against humanity or other acts of similar transcendence and seriousness, we are referring to conducts that are undoubtedly recognised as criminal in all systems of the world. But it is one thing to say that murder, extermination, and torture were already 'manifestly illegal' in all domestic systems when those aberrant acts were committed; ${ }^{106}$ it is quite another to classify them legally as crimes against humanity and to apply a special regime based precisely on that classification. In other words, although the generically criminal nature of such conducts was undoubtedly known at the time, there was no clear and precise definition of the constitutive elements that had to be met in order to classify them as international crimes.

Finally, international norms, both conventional and customary, lack another essential element for shaping a criminal offence: the provision of the corresponding penalty.107 This lacuna is due to their nature as rules of Public International Law, but it needs to be filled when we move within the framework of Criminal Law as applied in Continental legal systems, where the requirement for double precision imposes on the legislator the definition of both the punishable conduct and the applicable penalties. ${ }^{108}$ Hence, as has been described, when setting the penalty, the courts take as a reference the sanctioning frameworks established by national legislation for ordinary offences that are somehow close to international crimes.

In short, the classification of past atrocities as crimes against humanity generates an evident conflict with the principle of legality as it is strictly conceived by legal systems of Continental tradition, such as those we are analysing. The only way to overcome this apparent incompatibility seems to open the door to a more relaxed concept of the principle of legality, in line with its understanding in International Law and above all with what is provided for by the clauses contained in Articles 14(2) ICCPR and 7(2) ECHR.

105 Ferdinandusse, supra note 4, p. 236 et seq., despite suggesting that these problems are 'greatly mitigated by the fundamental character of many of the core crimes'.

106 Cassese, supra note 81, pp. 24-25.

107 E. Malarino, 'Argentina', in K. Ambos and E. Malarino (eds.), Persecución penal nacional de crímenes internacionales en América Latina y España (Konrad Adenauer Stiftung, Montevideo, 2003), p. 6o.

108 Argentine Supreme Court, Simón case, supra note 27, Judge Fayt's dissenting opinion, paras $35^{-36}$. The same requirement does not apply, though, in other legal traditions (common law, Islamic), nor in international norms, as it is reminded by Ferdinandusse, supra note 4, p. 248 et seq., concluding that the lack of a specific indication on penalties should not be an obstacle to the direct application of international norms as criminalising sources. In my view, this requisite cannot be put aside in those systems (of Continental tradition) that expressly envisage it. 
This concept should be applied exclusively to core international crimes, whose special nature, international significance, and gravity would easily justify such differentiated treatment. We find this idea in a series of rulings by the Colombian Supreme Court of Justice, which has gradually affirmed a principle of flexible legality in relation to international crimes. The first judgment in which this concept appeared was issued in 2010 in the proceedings against Bánquez Martínez, ${ }^{109}$ where the facts were classified as crimes against persons protected by international humanitarian law (IHL) (which is a different label for war crimes), although the offences so denominated were provided for in the Colombian system only from 25 July 2001, date of entry into force of the new Criminal Code (Law 599/2000). ${ }^{110}$ This is because it is considered sufficient that, at the time the crimes were committed, the country had signed and ratified the international treaties that impose the provision and punishment of such criminal conduct (such as the Geneva Conventions or the Convention on Genocide), assuming from then on the corresponding obligation to prosecute. ${ }^{111}$

After stressing that 'the principle of legality is the heritage of modernity and the central achievement of human rights, ${ }^{112}$ it is recognised that the construction of International Criminal Law has involved a 'redefinition' of this principle in terms of the sources of law, which extend to 'treaties, custom, general principles of law, case law and international doctrine' ${ }^{113}$ The Court justifies this change as follows:

Such a relaxation of the law, which implies a restriction of the safeguards of the defendant to give primacy to the fight against crimes against humanity, is explained by the fact that it is often a criminal phenomenon sponsored —or systematically committed — by totalitarian States, which of course would not be interested in legislating to criminalise their own acts. ${ }^{114}$

109 Colombian Supreme Court, Criminal Cassation Chamber, Banquez Martínez, Úber Enrique (case no. 33.039, rapporteur J.L. Bustos Martínez), Judgement, 16 December 2010. The case refers to several massacres perpetrated between the end of 1998 and 2001 by a block of the paramilitary group United Self-Defence Forces of Colombia.

$110 \quad$ Ibid., p. 34.

111 See also Colombian Supreme Court, Criminal Cassation Chamber (case no. 33118), Order, 13 May 2010.

112 Banquez Martínez, supra note 109, considerations, 'The Second Problem', para. 1, p. 25 (free translation).

113 Ibid., p. 3 .

114 The Court seems to ignore the fact that this justification does not seem to be applicable to the Colombian situation, since the criminal acts that are the object of the proceedings 
However, in affirming the existence of this relaxed concept of legality, the Court insists that 'it is applicable exclusively to the four categories of so-called international crimes, namely crimes of genocide, aggression, crimes against humanity and crimes against international humanitarian law'.15 It therefore creates a sort of double track, in relation to these specific categories of offences. ${ }^{116}$

The same reasoning also appears in subsequent judgments: for example, in a judgment concerning the alleged forced disappearances committed by the Armed Forces during the operation to subdue the attack carried out by the M-19 on the Palace of Justice in 1985, the Supreme Court followed the same interpretation to conclude that, due to the jus cogens nature of IHL norms, the acts prosecuted could be classified as crimes of forced disappearance of persons, despite the fact that this concept was specifically defined in Colombian legislation at a later date. ${ }^{117}$

Opening the way to the application of this principle of flexible legality, thus creating a double track for international crimes, may be a valid interpretative solution to overcome the objections, mentioned above, generated by the retroactive application of international normative sources for the legal classification of the facts.

Three points can be raised here: firstly, it can be argued that, between the two possible interpretations of the principle of legality, in the systems analysed, the stricter one should prevail in any case, not only because it is expressly stated in the Constitutions of those countries, but also because it grants a wider protection (for the accused and therefore for any citizen) than the broad concept accepted in International Law. ${ }^{118}$

cannot be attributed to a totalitarian State (Colombia never became one, throughout the armed conflict), but are part of an armed conflict and are also the responsibility, in this specific case, not of State institutions, but of a paramilitary group.

$115 \quad$ Ibid., p. 34 (free translation).

116 Gallant, supra note 18, p. 39.

117 Colombian Supreme Court, Criminal Cassation Chamber, L.A. Plaza Vega (case no. 38957), Judgement (SP17466-2015, rapporteur L.G. Salazar Otero), 16 December 2015, considerations, para. 2. See also Colombian Supreme Court, Criminal Cassation Chamber, J.T. Espitia Supelano et al. (SP744-2016/44462, rapporteur L.G. Salazar Otero), 27 January 2016. A similar exception for serious crimes can also been found in German decisions concerning Nazi and Borderguards crimes and in national jurisprudence of other countries, as well as in some Criminal Codes (e.g., Bosnia and Herzegovina) and Constitutions (e.g., Canada): Ferdinandusse, supra note 4, p. 224 et seq.

118 Gil, supra note 72, p. 159. More doubtful on this point is Ferdinandusse, supra note 4, p. 230. 
Secondly, the provision for a stricter concept of this principle in the Rome Statute (Articles 22 and 23) may be seen as a trend towards elevating the international principle of legality to a stricter level. ${ }^{119}$ The conception of legality consolidated in the domestic systems analysed would be in line with such evolution.

Lastly, the creation of this double track would, in my opinion, require a clear determination of the core of offences for which a relaxation, so to speak, of the principle of legality is permitted, by way of exception. But the perimeter of these categories is not, in practice, as clearly fixed as one might think: there are numerous sentences, in Latin American jurisprudence itself, in which an expansive interpretation of these criminal figures is proposed. ${ }^{120}$ The risk, then, is that the differentiated route that has been created for a small number of crimes, namely, core international crimes (and for which there would undoubtedly be solid legal standing), ends up being applied to conduct that

11 Cassese, supra note 81, pp. 24-27; B. Broomhall, 'Article 22', in O. von Triffterer and K. Ambos (eds.), The Rome Statute of the International Criminal Court. A Commentary, $3^{\text {rd }}$ edn. (C.H. Beck-Hart-Nomos, München, 2016), pp. 949-958; H. Olásolo, 'A Note on the Evolution of the Principle of Legality in International Criminal Law', 18 Criminal Law Forum (2007), 301-319, stating that this choice is due to the consideration of the inability of customary norms to assure legal certainty. The Rome Statute encompasses the prohibition of retroactivity and of analogy (although some scholars consider that the latter is limited to the analogia legis, but allows the analogia iuris, which fills normative gaps having resort to the general principles of law: Cassese, supra note 81, p. 34), the rule of strict construction and the principle in dubio pro reo. Yet, on the one hand, it has been stated that such strict version of the principle of legality applies only to the construction of the crimes under the Statute (according to the wording of Article 22(2)), but not to other rules thereby contained (Broomhall, supra in this same note, p. 949 et seq.; against this view, K. Ambos, Treatise of International Criminal Law. Vol. I: Foundations and General Part (Oxford University Press, Oxford, 2013), p. 9o). On the other hand, the system of normative sources that the ICC can apply according to Article 21 Rome Statute is broad and diverse, far from following the 'reservation of law' (in this case, reservation of Statute) mandate.

120 See, for example, the several Argentine judgements that, following an idea proposed for the first time by a Spanish court (Spanish National Court, Plenary Session of the Criminal Law Chamber, 'Resolution declaring the Spanish judiciary competent over crimes of torture, genocide and terrorism perpetrated in Argentina' ( ${ }^{\text {rd }}$ Section, Case no. 19/97, Central Investigative Judge no. 5), 4 November 1998), have labelled the atrocities committed against political dissidents in Argentina as genocide, by virtue of a wide interpretation (amounting, in my view, to a in malam partem analogy) of the concept of 'national group' that the relevant provision protects against that crime: Federal Criminal Trial Court of La Plata, Etchecolatz, Miguel Osvaldo (case no. 2251/o6), Judgement, 19 September 2006, section IV(B); Same judicial body, Von Wernich, Christian Federico (case no. 2506/o7), Judgement, 9 October 2007, section $\mathrm{v}(3)$. For a more specific analysis of this jurisprudential line, see Maculan, supra note 8, pp. 156-169. 
does not have the same legal standing. This in turn favours the instrumentalisation of the category for spurious purposes (for example, to silence political dissidence) and, in the best of cases, ends up trivialising the seriousness and exceptionality of international crimes. The admission of a double-track principle of legality, combined with the expansive trend of international crimes that is also registered in Latin American case law, poses the risk of an excessive broadening of this special sub-area of Criminal Law.

These three considerations show that the interpretative solution that seems to be most advisable in these cases, i.e., the admission of a differentiated or flexible principle of legality for international crimes, also poses some problems.

\section{$4 \quad$ Alternative Interpretative Proposals}

In view of the difficulties generated by the interpretative technique of dual classification, it may be appropriate to explore the possibility of other lines of reasoning that would make it possible, in cases such as those analysed, to achieve the same results (allowing criminal prosecution, and where appropriate, punishment, of those responsible for past atrocities) without impinging on the fundamental principles of criminal law.

Firstly, with regard to the obstacle created by the existence of amnesties or similar provisions, it must be remembered that the evolution of International Human Rights Law in recent decades has led to a growing rejection of these measures. Without being able to analyse here the complex and debated role of amnesties for serious human rights violations, ${ }^{121}$ there is now a consensus on the inadmissibility of self-amnesties (of which there are several examples in Latin American democratic transitions) $)^{122}$, while democratic and conditional amnesties, which a strict position (embodied, among others, in the IACtHR) does not admit either, can, according to a more flexible interpretation, have a place in transitional contexts. ${ }^{123}$

\footnotetext{
121 For a full picture of this controversial issue, both from a historical and legal perspective, see Close, supra, note 8.

Examples of self-amnesties are those issued by Fujimori's government in Peru, by Pinochet in Chile and the Argentine 1983 "Law of National Pacification", later derogated by the restored democratic Government. See Close, supra, note 8, pp. 103-107. 
Latin American transitional experiences have been marked by constant pressure to eliminate amnesty and pardon measures, and in most cases, these have been repealed and/or declared unconstitutional. ${ }^{124}$ The declaration of unconstitutionality of the Full Stop and Due Obedience Laws in Argentina in the Simón case is perhaps the best known example of this trend, and has allowed the reopening of criminal proceedings that had been paralyzed by the effect of these laws. ${ }^{125}$ In those countries where amnesty laws (or other measures which, although nominally different, produce a similar effect) are still in force, these are in any case democratic amnesties, subject to defined material limits and often conditional, ${ }^{126}$ and they are legitimised within the framework of the delicate balancing of interests and objectives inherent in transitional justice. ${ }^{127}$ Therefore, the possibility of criminal prosecution for past atrocities depends here not on the classification of facts, but on the position about the admissibility of certain kind of amnesty.

Secondly, even where the invalidation of amnesty provisions has enabled criminal prosecution to be reactivated, the problem of statutes of limitations persists, and it is indeed the main aspect on which the judgements analysed focus. In order to overcome this obstacle, some judgments handed down in Latin-American jurisprudence offer an alternative solution that seems particularly interesting.

amnistie nel diritto internazionale (CEDAM, Padova, 2011), p. 259 et seq.; L. Mallinder, Amnesty, Human Rights and Political Transition. Bridging the Peace and Justice Divide (Hart, Oxford, 2008); Teitel, supra note 10, p. $5^{2}$ et seq.

124 Close, supra note 8, pp. 170-172; Mallinder, supra note 14; Almqvist and Espósito, supra note 6; F. Lessa and L. Payne (eds.), Amnesty in the Age of Human Rights Accountability: Comparative and International Perspectives (Cambridge University Press, Cambridge, 2012).

125 Argentine Supreme Court, Simón case, supra note 27. The judgement grounded its findings mainly in the Inter-American jurisprudence, focusing on the Barrios Altos precedent. For a comment, see C.A.E. Bakker, 'A Full Stop to Amnesty in Argentina: The Simón Case', 3 Journal of International Criminal Justice (2005) 1106-1120.

126 This would be the case of Uruguay, whose Law no. 15848, passed by the Parliament on 21.12.1986 ('ley de caducidad de la pretensión punitiva'), and later upheld in two popular plebiscites (in 1989 and 2009), has been nevertheless declared incompatible with the State's international duties by the IACtHR in the controversial Gelman v. Uruguay, Judgement, 24 February 2011. Similarly, Brazilian amnesty law of 1979, confirmed and expanded by the new democratic Constitution of 1988, was part of a process of political liberalisation, and yet it was declared inadmissible by the IACtHR in the Gomes Lund v. Brasil Judgement, 24 November 2010. These two cases confirm the IACtHR's strict approach when assessing the validity of amnesties.

Maculan and Gil, supra note 12, p. 149. 
This line of reasoning affirms that the time barring should be considered suspended during the dictatorial regime in which the abuses were committed. Such idea is predicated on the state of exception in which the criminal acts were carried out. Dictatorial regimes were characterised by the suspension, de jure or de facto, of a series of safeguards, and by the impossibility of taking criminal action against those responsible for the offences perpetrated in the context of mass violence. According to this proposal, while this situation of generalised suspension of the rule of law was maintained, the statute of limitations, which is designed for a context of normal functioning of the judicial system, could not begin to run. ${ }^{128}$ It would be totally contrary to constitutional principles to allow the statute of limitations to run according to ordinary time limits at the same time as criminal proceedings were paralysed by an authoritarian regime, which was also responsible for the unlawful acts. ${ }^{129}$

A detailed explanation of this argument is provided by the judgement handed down by a court in Montevideo against the former Uruguayan dictator Bordaberry, which applies it to the offence of subversion of the Constitution..$^{130}$ The court states that, since the rule of law did not apply during the dictatorship, and it was impossible to 'guarantee the conduct of a trial under the due process rules', the statute of limitations cannot be considered to have expired while

Another interpretation that also emphasises the regime of exception of the dictatorships appears in some Chilean sentences, which highlight how the country was 'in a state or time of war' by express provision of decree-laws approved by the Pinochet regime. However, precisely because it was in a state of war, the Geneva Conventions and other relevant customary laws were applicable, which would turn deaths and other acts committed in violation of those laws into international crimes: see e.g., Chilean Supreme Court, Second Chamber, Case no. 469-98, Disappearance of Pedro Poblete Córdova, Judgement, 9 September 1998 and, for a commentary, K. Fernández Neira, 'Breve análisis de la jurisprudencia chilena, en relación a las graves violaciones a los derechos humanos cometidos durante la dictadura military', 8(1) Estudios Constitucionales (2010) 467-488. Background to this argument can be found in German case law, with regard to offences committed during the period of validity of the German Democratic Republic, which according to ordinary rules should have been declared time-barred. The German courts therefore began to assert that the period considered for the statutory limitation was suspended until 3 October 199o, the date of entry into force of the Unification Treaty; this position was later confirmed at legislative level by three laws on statutory limitations: see G. Fornasari, 'La prescrizione penale nella giurisprudenza delle corti sovranazionali', Diritto penale XXI secolo (2017), pp. 71-74.

First Instance Tribunal in Criminal Matters (Juzgado de Primera instancia en lo Penal de $7^{\circ}$ turno), Judge Motta, Bordaberry Arocena, Juan María, Judgement, 9 February 2010. For a commentary on the ruling: G. Fornasari, 'Dictadores al banquillo. El "caso Bordaberry" como piedra miliar de la justicia de transición en Uruguay', in P. Galain Palermo (ed.), Justicia de transición? Mecanismos políticos y jurídicos para la elaboración del pasado (Tirant lo Blanch, Valencia, 2016), 171-204. 
this situation continued. ${ }^{131}$ In the absence of a specific rule, in the Criminal Code, suspending the running of the limitation period in an exceptional situation, the court takes as a reference the discipline contained in the Civil Code, which expressly provides for the case of 'just cause'. The statute of limitations would therefore begin to run from the time when a situation of democratic normality was restored, in which the country's institutions and judicial bodies were not subject to illegitimate impediments.

The same interpretation appears, in addition to the Spanish judge Baltasar Garzón's order in the case for crimes under Franco's regime, ${ }^{132}$ in a judgment issued by the Peruvian Constitutional Court following an appeal for habeas corpus filed by a man convicted of the massacre in Accomarca (Peru). ${ }^{133}$ In this pronouncement the constitutional judge confirms the classification of the facts as the crime of murder proposed by the court $a$ quo, as well as its classification as international crimes, as such imprescriptible. ${ }^{134}$ But in the alternative, it affirms the suspension of the statute of limitations while the amnesty laws approved by Fujimori's government were in force, since they made it impossible to exercise criminal action according to ordinary criteria. The court concluded that the statute of limitations began to run only after the partial trial before the military court was annulled, as a result of the declaration of unconstitutionality of the amnesty laws in 2002..$^{135}$

This solution allows to overcome the statute of limitations obstacle by relying on domestic norms that were in force at the time when the facts occurred. Defendants are charged with domestic offences, already envisaged in criminal legislation prior to those facts, and the limits for time barring are not changed to the detriment of defendants; yet prosecution is still possible because of

$131 \quad$ Ibid., para. 1: 'prior exception to the statute of limitations'.

132 Spanish National Court, Central Investigative Chamber no. 5, Preliminary Proceedings, case no. 399/2006 V, Decision of 16 October 2008. For a critical commentary: A. Gil Gil, $L a$ justicia de transición en España. De la amnistía a la memoria histórica (Atelier, Barcelona, 2008), specifically on this point p. 163 .

133 Peruvian Constitutional Court (Tribunal Constitucional), Contreras Roberto (case no. o0218-2009-PHC/TC), 11 November 2010. The subject of the case was a massacre committed on 14 August 1985 in the town of Accomarca (Ayacucho), in which 69 peasants died. The court of first instance had declared the statute of limitations for the crime, qualified as murder, but the sentence was modified by the National Criminal Court which subsumed the facts under the category of genocide, and therefore declared them not subject to the statute of limitations. One of those responsible for the massacre, Roberto Contreras Matamoros, lodged an appeal for habeas corpus with the Constitutional Court, insisting that the facts should be qualified as murder and declared time-barred. The Constitutional Court dismissed the appeal.

134 Ibid., 'Background', para. 4.

135 Ibid., Reasoning 19. 
the suspension of the statute of limitations during the dictatorship or, where appropriate, during the armed conflict. Such proposal keeps intact the principle of legality, also in its strictest version, and is therefore clearly preferable, in my view, to the direct and retroactive application of international rules. ${ }^{136}$ Additionally, the argument highlights the illegitimacy of the regime that committed the atrocities (or the exceptionality of the situation), and thus gives grounds for the application of a special rule.

A matter that should be more carefully assessed, though, is the determination of the moment when the limitation period ceases to be suspended: this could be the holding of the first democratic elections after the fall of the dictatorship, or the signing of the peace treaty marking the end of an armed conflict, or the taking up of office by the new Parliament, or any other moment that clearly marks the end of this exceptional situation that has prevented the proper functioning of the criminal justice system. Although the determination of a clear starting point for transitional processes is usually hard and contentious, the selection (ideally, by means of a legislative provision) of a conventional moment in which the suspension ceases would help to avoid inconsistencies in jurisprudence and to guarantee both the principles of legal certainty and equality before the law.

Finally, another consequence of the classification of the facts as international crimes is, as has been recalled, the application of the principle of universal jurisdiction. This aspect, despite being at the origins of the technique of dual classification, does not actually appear in the Latin American case law analysed, since criminal proceedings are carried out before the courts of the country in which the acts were committed.

In this regard, it should be recalled that the possibility of exercising criminal jurisdiction over cases not directly related to that country is regulated independently and differently in each legal system, although there is a clear convergence towards the inclusion of core international crimes in its scope. ${ }^{137} \mathrm{In}$ addition, this option is normally taken in cases that have no possibility of criminal prosecution in the system that would have the jurisdiction in the primary route (by virtue of the territoriality and personality principles). For this reason,

136 In the same line, Pastor affirms: 'it is questionable ... the fact that absolute nonapplicability of statutes of limitation has become widespread where it would have been appropriate to establish nothing more than a suspension of the statute of limitations while the prosecution of the facts was obstructed by the actual power of the authors or their accomplices' (D. Pastor, 'La imprescriptibilidad de los crímenes internacionales en conexión con el fenómeno del terrorismo', in J.R. Serrano-Piedecasas and E. Demetrio Crespo (eds.), Terrorismo y estado de derecho (Iustel, Madrid, 2010), 641-653, p. 647). 
it may be ventured that the removal of obstacles to criminal prosecution posed by amnesties and statutes of limitations (based on the arguments explained in this same section) would make it increasingly unnecessary to resort to universal jurisdiction for the past atrocities committed in Latin American countries. The growing assumption of responsibility by the States for the commission of the unlawuful acts and their commitment to the investigation and criminal prosecution thereof, which are becoming a reality under the restored democratic regimes and once the transitional phase itself is over, would undoubtedly be the most desirable path for an effective and reasonable fight against impunity.

\section{5}

\section{Concluding Remarks}

The courts that must prosecute the atrocities committed during the dictatorships and armed conflicts that have plagued the Latin American continent face a dilemma that is very difficult to resolve. If they classify the facts as ordinary crimes, on the one hand, they fail to reflect the gravity and massiveness of the facts, and on the other, they come up against the statute of limitations, or the effects of amnesty laws, or other limits on the exercise of criminal action. On the other hand, if they classify the facts as international crimes, an option that would allow all these obstacles to criminal action to be overcome, they generate a significant tension with the principles of legality and non-retroactivity.

The hermeneutic technique of the dual classification of facts, by jointly applying the categories of ordinary offences and international crimes, aims to combine the advantages of each of these qualification options and thus break this deadlock. According to this method, the ordinary offence offers the definition of the conduct and the applicable sanction, while the international crime permits a better description of the gravity and widespread nature of the facts (with a purely communicative-symbolic effect, or, sometimes, leading to an aggravation of the penalty) and, above all, to apply its special regime against impunity.

However, a more detailed analysis shows that this technique has methodological flaws: firstly, it alters the order and functioning of the judicial procedure for classifying the facts, secondly, it creates by judicial means a new type of crime, different from the two initial ones, and thirdly, it fails to define the relationship between the two criminal categories applied in a combined manner, and, where it defines it as a relationship of specialty, it disregards the sanctioning rules associated with this assumption. 
Moreover, even the combined application of two criminal categories fails in dampening down the conflict between recourse to international sources as incriminating rules and the principles of legality and non-retroactivity, as they are strictly conceived in the legal systems where this jurisprudence has been developed. International custom does not meet the requirements of lex scripta, stricta et certa, even if it can be shown to have existed prior to the commission of the crimes. Conventional sources, on the other hand, are written, but do not respect the lex praevia requirement, having come into force at some time after the events. And neither of them contains another essential element for the principle of legality, i.e., the clear and prior determination of the sanctions applicable to those who carry out the prohibited conduct.

The only way to overcome these criticisms seems to be to admit a 'flexible legality principle' (as some Colombian jurisprudence suggests), closer to the international interpretation of it, in line with the exception clauses of Articles 15(2) ICCPR and 7(2) ECHR. This broader and more lax understanding of the principle is intended to be limited to core international crimes, thus creating a double track, which differs from the strict concept generally recognised by the constitutional and criminal norms of those systems.

This idea, which can be legitimised by the international significance and special nature of the crimes, is not without risk: firstly, it lends itself to an uncontrolled expansion of its scope, especially if we combine it with the difficulty to establish a clear perimeter of the category of international crimes and with the jurisprudential tendency (evident in Latin American case law) to apply it very broadly. Secondly, it gives rise to the possible misuse of this differentiated route for political reasons, as always does the creation of an "exceptional track": even when it is grounded on the noblest reasons, ${ }^{138}$ it opens a breach in the constitutional and criminal safeguards "wall" that may be easily perverted to reach illegitimate goals, such as the criminalisation and conviction of political dissent.

In view of the tensions and risks thus generated by the dual classification technique, alternative paths have been explored to ensure the criminal prosecution of atrocities committed in the past. Thus, overcoming amnesty and similar provisions requires intervention by legislators (with the repeal of these laws) or the constitutional judge (with the declaration of their unconstitutionality), but in reality this is no longer a problem for most of the systems that have been considered.

138 A. Garapon, Les gardiens des promesses. Justice et démocratie (Odil Jacob, Paris, 1996), p. 82. 
According to a proposal found in the same Latin American case law, the statute of limitations for crimes can be waived by alleging the suspension of the period of limitation during the entire regime de facto (or, as the case may be, during the armed conflict), because it was a situation that prevented the normal functioning of the judicial system. This solution, which should imply a clear and uniform determination of the moment when the statute of limitations resumes, also at the same time highlights the illegitimate nature of regimes tainted by the commission of atrocities.

Finally, the application of the principle of universal jurisdiction, for which the classification of the facts as international crimes paves the way, should become an increasingly unnecessary option, as countries where the offences were perpetrated commit themselves to their investigation and prosecution.

In conclusion, the dual classification technique offers an extremely interesting proposal for dealing with the problems posed by the criminal law response to acts committed at a time when many of the current rules of International Criminal Law had not yet been consolidated (inapplicability of statutes of limitations, inadmissibility of amnesties—at least— that are self-granted and absolute). In developing it, judges have shown their genuine commitment to justice and to the claims legitimately expressed by the victims of the crimes and by large sectors of society in the face of acts of such magnitude and atrocity.

While recognising these positive aspects, this article has also sought to reflect the existence of a 'dark side' to this hermeneutic method, in order to be aware of all its implications and the intrinsic difficulty of reconciling two interests in permanent conflict: respect for the fundamental principles consolidated in Criminal Law, on the one hand, and the will to provide an adequate and proportionate response to atrocious crimes and to prevent impunity from them, on the other. 